\title{
Geneza matematyki wedle kognitywistów
}

\author{
The origin of mathematics
}

\section{according to cognitive scientists}

\author{
Jerzy Pogonowski \\ InSTytut JęZy KOZNAwstwa, Uniwersytet im. AdAMA MickiewicZA \\ Al. NiePodlegŁoŚCI 4, 61-874 PoZnAŃ \\ pogoneamu.edu.pl
}

\begin{abstract}
This note is a critical presentation of the ideas proposed in (Lakoff, Núñez 2000). We doubt in their adequacy.
\end{abstract}

\section{Wstęp}

Celem tej notatki jest krytyczne przybliżenie czytelnikom ustaleń ze stosunkowo niedawno opublikowanej książki (Lakoff, Núñez 2000). Autorzy to znani specjaliści nauk kognitywnych. Tym razem postanowili wykazać, że to właśnie procesy metaforyzacji są odpowiedzialne za tworzenie podstawowych pojęć, a nawet całej struktury współczesnej matematyki. Odwołują się przy tym do ustaleń ze znanej monografii (Lakoff, Johnson 1980), ale także do wielu nowszych prac. Nasze omówienie dzielimy na części odpowiadające częściom analizowanego tekstu. Uwagi krytyczne zamieszczamy zarówno w poszczególnych częściach, jak też na końcu tekstu, w punkcie 6.

Książka jest - wedle deklaracji autorów - wstępem do analizy pojęć matematycznych. Nie jest ani pracą matematyczną, ani rozprawą z filozofii matematyki. 
Nie stanowi też bezpośredniego przyczynku do ustaleń z historii matematyki. Jej głównym natomiast celem jest ukazanie matematyki z perspektywy nauk kognitywnych. Przy tym - w zgodzie z podtytułem książki - perspektywa ta uwzględnia fakt, poświadczany empirycznie, że umysł jest ucieleśniony (embodied mind). Uprawianie nauki, w tym matematyki, kształt kultury, organizacja doświadczenia potocznego wreszcie - wszystko to, zdaniem autorów, musi być tłumaczone w świetle tego podstawowego faktu.

We wstępie autorzy wyliczają niektóre składniki mitologii matematycznej (The Romance of Mathematics), z którymi przyjdzie im się zmierzyć w próbie kognitywnego spojrzenia na matematykę. Dają one, ich zdaniem, fałszywy obraz matematyki, przejawiający się w następujących stwierdzeniach:

1. Matematyka jest rzeczywista, choć jest abstrakcyjna i odcieleśniona.

2. Matematyka istnieje obiektywnie, dostarczając struktury dla całego uniwersum, a także wszelkich innych możliwych uniwersów. To istnienie jest niezależne od istnienia ludzi lub w ogóle jakichkolwiek istot, przekracza je.

3. Ludzka matematyka jest jedynie częścią abstrakcyjnej, transcendentalnej matematyki. Tak więc, dowody matematyczne pozwalają nam odkrywać transcendentalne prawdy o uniwersum.

4. Matematyka jest częścią świata fizycznego i dostarcza mu racjonalnej struktury. Istnieją, dla przykładu: ciagi Fibonacciego w kwiatach, spirale logarytmiczne w skorupach ślimaków, fraktale w zarysach gór, parabole w rzutach oraz liczba $\pi$ w sferycznych kształtach planet, gwiazd oraz baniek mydlanych.

5. Matematyka charakteryzuje nawet logikę, a zatem także strukturę rozumowania, przy tym dowolną postać rozumowania, dowolnych istot.

6. Uczenie się matematyki to zatem uczenie się języka natury, sposobu myślenia, który musi być wspólny dla wszelkich wysoce inteligentnych istot wszędzie w kosmosie.

7. Ponieważ matematyka jest odcieleśniona, a rozum jest postacią logiki matematycznej, sam rozum jest odcieleśniony. Wynika z tego, że - w zasadzie - maszyny mogą myśleć.

Wszystkie te przekonania autorzy uważają za fałszywe, za rodzaj przesądów na temat istoty oraz roli matematyki. W całym dalszym tekście autorzy przytaczają argumenty przeciw trafności powyższych przekonań. Są to argumenty wskazujące na przede wszystkim metaforyczną naturę pojęć matematycznych. Odnosi 
się to, jak zobaczymy, do podstawowej metafory matematycznej, z jaką związane jest rozumienie pojęcia nieskończoności w matematyce. Przejawia się owa metaforyczność także we wszelkich dziedzinach i na wszelkich poziomach uprawiania matematyki, dla przykładu, wedle autorów:

1. Liczby są metaforycznie przedstawiane jako punkty na osi liczbowej.

2. W algebrze Boole'a zbiorów tworzenie obiektów jest ujmowane metaforycznie w terminach operacji algebraicznych.

3. W logice matematycznej rozumowania są metaforycznie przedstawiane jako rachunki na symbolach.

4. W przypadku funkcji trygonometrycznych kąty są metaforycznie przedstawiane jako liczby.

5. Mnożenie liczb zespolonych przedstawiane jest metaforycznie na płaszczyźnie zespolonej w terminach obrotów.

Te oraz dalsze metafory omawiane są szczegółowo w kolejnych rozdziałach. Niektóre metafory mają strukturę wielopoziomowa - bazowane są na innych metaforach. Ponadto, oprócz analizy zwykłych w takich przypadkach konstrukcji (dziedzina odniesienia, dziedzina docelowa, związki inferencyjne), autorzy podkreślają także rolę złaczeń metaforycznych (metaphorical blends). Cała koncepcja Lakoffa i Núñeza wspierana jest ustaleniami współczesnych nauk kognitywnych. Obok szczegółowych wyników eksperymentalnych autorzy przywołują wnioski oraz hipotezy natury ogólniejszej, np.:

1. Ucieleśnienie umystu. To sama natura naszych ciał, mózgów oraz codziennego funkcjonowania kształtuje ludzkie pojęcia i rozumowania, w szczególności matematyczne.

2. Nieświadomość poznawcza. Większość myśli jest nieświadoma, nie w sensie Freudowskim, lecz po prostu jest niedostępna bezpośredniej świadomej introspekcji. Nie możemy przyjrzeć się bezpośrednio naszym systemom pojęciowym i procesom myślowym przebiegającym na niskim poziomie. Większość myślenia matematycznego taki ma właśnie charakter.

3. Myślenie metaforyczne. Istoty ludzkie w większości ujmują pojęciowo abstrakcje w terminach konkretnych, używając pojęć i sposobów rozumowania ugruntowanych w systemie sensoro-motorycznym. Przez metafore pojeciowq rozumie się mechanizm, w wyniku którego abstrakcje są uchwytywane w terminach konkretnych. Matematyka powszechnie stosuje metafory pojęciowe. 
Wyniki badań nauk kognitywnych skłaniają do tezy, że mózg nie jest wcale „urządzeniem całkiem ogólnego przeznaczenia” (general-purpose device). Służy on przetwarzaniu informacji dotyczącej: widzenia, ruchu, orientacji przestrzennej, wzajemnych oddziaływań interpersonalnych, emocji, języka, potocznych rozumowań. Język i człowiecze pojęcia nie są losowe i dowolne - są wysoce zorganizowane i wielce ograniczone, a to ze względu na ograniczenia i strukturę mózgu, ciała oraz świata zewnętrznego. W odniesieniu do samej matematyki powyższe ustalenia każą zadać m.in. następujące pytania:

1. Jakie konkretnie mechanizmy działania ludzkiego mózgu oraz umysłu pozwalają ludziom na tworzenie pojęć matematycznych oraz rozumowania matematyczne?

2. Czy matematyka ugruntowana na mózgu i umyśle jest całą istniejaca matematyką? Czy też rację bytu ma matematyka w duchu Platońskim, przekraczająca ciała i umysły oraz nadająca strukturę kosmosowi (temu oraz wszystkim możliwym)?

Książka stara się odpowiedzieć głównie na pierwsze z tych pytań, przy czym nie jest to - bo być nie może - odpowiedź udzielana wewnatrz matematyki. Terenem, na którym tych odpowiedzi się udziela są nauki kognitywne.

Natomiast pytanie drugie to jedno z podstawowych pytań filozofii matematyki. Odpowiedź proponowana przez autorów jest taka oto:

1. Twierdzenia dowodzone przez ludzi pozostają w dziedzinie ludzkiego systemu pojęć matematycznych.

2. Cała wiedza matematyczna, którą mamy lub możemy uzyskać to wiedza wewnątrz ludzkiej matematyki.

3. Nie ma żadnego sposobu, aby przekonać się, czy twierdzenia dowodzone w ludzkiej matematyce mają jakąkolwiek prawdziwość obiektywną, zewnętrzną wobec istot ludzkich lub innych.

Na pierwszy rzut oka sformułowania te mogą sprawiać wrażenie nieco tautologicznych. Autorzy starają się jednak podawać bardziej rozbudowane argumenty za ich trafnością, np.:

1. Problem istnienia matematyki rozumianej po Platońsku nie może być rozważany na drodze naukowej. Byty Platońskie nie mogą być percypowane przez ciało, mózg, umysł. Nauka nie może dowieść ani obalić twierdzenia o istnieniu bytów Platońskich, podobnie jak w przypadku istnienia lub nieistnienia Boga. 
2. Rozumienie matematyki przez ludzi polegać może jedynie na ujęciu jej w terminach dostępnych mózgowi oraz umysłowi.

3. To, czym jest ludzka matematyka jest empirycznym problemem naukowym, a nie problemem matematycznym ani filozoficznym. Tak więc, jedynie nauki kognitywne, badające mózg, umysł oraz wiążące je zależności są w stanie odpowiedzieć jaka jest istota ludzkiej matematyki. W konsekwencji, całość matematyki to ludzka matematyka.

4. Gdyby jednak uważać pytanie o istotę matematyki nie za pytanie naukowe lecz filozoficzne (albo i nawet religijne), to $\mathrm{np}$. istnienie rzekomego Platonskiego świata matematyki oraz obiektywność jej prawd uzasadniane byłyby na drodze, która obecnie nie może zostać uznana za naukową.

\section{Arytmetyka}

Umiejętności matematyczne - choć oczywiście w skromnym zakresie - poświadczane są eksperymentalnie u ludzkich noworodków. Sprytnie przeprowadzane doświadczenia uwzględniające czas (a więc także intensywność) uwagi zwracanej przez noworodki na manipulacje niewielkim liczbami przedmiotów pozwalaja postawić tezę, że dla takich minimalnych dziedzin, liczących do około czterech elementów noworodki są w stanie zdawać sobie sprawę z działań dodawania oraz odejmowania.

Niezależnie od kultury oraz wykształcenia, wszyscy ludzie dysponują zdolnością bezrefleksyjnego, natychmiastowego ustalenia z jaką niewielką liczbą obiektów mają do czynienia - ogranicza się to do co najwyżej (mniej więcej) czterech obiektów. Przy większej liczbie obiektów wymagana jest już pewna refleksja, działania polegające na porządkowaniu i liczeniu. Tę uniwersalną bezrefleksyjną umiejętność autorzy nazywają subitizing. Podkreślić należy, że nie mówi się tu o manipulacjach na symbolach, lecz jedynie na samych obiektach. Odnosi się ona nie tylko do wzroku, ale także np. do wrażeń słuchowych. Podobne umiejętności arytmetyczne poświadcza się również u Braci Mniejszych, nie tylko naczelnych.

Poświadcza się eksperymentalnie, że uszkodzenia w obrębie zakrętu kątowego (angular gyrus) (znajdującego się w dolnej korze ciemieniowej (inferior parietal cortex)) wiążą się z utratą zdolności arytmetycznych. Należy zwrócić uwagę, że zakręt kątowy jest anatomicznie położony w rejonie, gdzie znajdują się powiązania neuronów związanych ze wzrokiem, słuchem oraz dotykiem.

W każdym języku etnicznym mamy do czynienia z wyrażaniem różnego rodzaju zależności przestrzennych, które - dla kognitywisty - stanowią podstawę do wyodrębnienia odpowiednich schematów obrazowych (image schemas). Przykładem takiego schematu jest: pojemnik (wraz z wnetrzem, brzegiem, zewnetrzem). 
Schematy związane są też z systemami zależności aspektowych. Ruch i jego wyrażanie dostarczają schematu źródto-droga-cel, itd.

Tworzymy metafory pojeciowe dokonując przyporządkowań z jednej dziedziny $\mathrm{w}$ inna - dla przykładu, w metaforze stany emocjonalne to miejsca $\mathrm{w}$ przestrzeni lub stany fizyczne przyporządkowujemy emocjom, uczuciom, itp. miejsca lub cechy fizyczne: być w depresji, żywić ciepłe uczucia, itp. Takich metafor pojęciowych jest niezliczone mrowie, wiele z nich opisano dokładnie w (Lakoff, Johnson 1980). Kategorie rozumiemy np. jako pojemniki, miłość jako partnerstwo (w cywilizacji Zachodu), itd.

Złacze pojęciowe to kombinacja dwóch różnych struktur poznawczych wraz z ustalonymi odpowiedniościami pomiędzy nimi. Jeśli te połączenia są metaforyczne, to mówimy o złq̨czu metaforycznym. Za przykład niech służy tu oś liczbowa, która korzysta z metafory liczby to punkty na prostej.

Pomijamy dyskusję wielu szczegółów dotyczących zdolności tworzenia metafor. Autorzy wyróżniają dwa typy metafor pojęciowych w matematyce:

1. Metafory bazujace. Dostarczaja podstawowych, bezpośrednio ugruntowanych pojęć. Dla przykładu: dodawanie jako grupowanie razem obiektów.

2. Metafory łqczqce. Dostarczają bardziej abstrakcyjnych pojęć. Dla przykładu: liczby to punkty na prostej, figury geometryczne to równania algebraiczne.

W przypadku arytmetyki autorzy omawiają głównie metafory pierwszego typu. W metaforze ujmującej arytmetykę jako grupowanie obiektów dokonują przyporządkowania kolekcjom obiektów, relacjom między nimi, operacjom na nich odpowiednio: liczb, relacji i operacji arytmetycznych. Uzyskują w ten sposób również ugruntowanie pewnych elementarnych praw arytmetycznych.

Inna metafora to arytmetyka jako konstruowanie obiektów. Operacje na częściach obiektów przetwarzane są na operacje arytmetyczne. Trzecia z kolei metafora to metafora odcinka pomiarowego - jego użycia w odniesieniu do obiektów fizycznych transponowane są na odpowiednie operacje na liczbach. Wreszcie, wspomina się o czwartej podstawowej metaforze: arytmetyka jako ruch wzdtuż drogi. Także tutaj obiekty fizyczne i relacje między nimi transponowane są na liczby i łączące je relacje.

Wspomniane wyżej cztery metafory odpowiedzialne są, zdaniem autorów, za traktowanie liczb jako rzeczy w świecie. To z kolei ma m.in. i tę konsekwencję, że metaforycznie ugruntowane zostają różne zasady domknięcia $\mathrm{w}$ arytmetyce: skoro operowanie na obiektach fizycznych pewnego rodzaju daje obiekty tego samego rodzaju, to pewne operacje w ustalonym systemie liczbowym nie wyprowadzają poza ten system. 
Wreszcie, podkreśla się, że rachunki dokonywane są na symbolach, a nie na samych liczbach. Tak więc, rachunki wykonywać można nawet całkowicie bezmyślnie, o ile tylko zna się odpowiednie algorytmy rachowania.

\section{Algebra, logika, zbiory}

Autorzy twierdzą, że połączenie ustaleń historycznych z wynikami badań kognitywnych pozwala lepiej rozumieć obowiązujące w matematyce standardy - przede wszystkim standard gruntowania poszczególnych teorii matematycznych na bazie aksjomatycznej. Standard ten - ujawniony po raz pierwszy w aksjomatycznym systemie geometrii Euklidesa - miałby się wywodzić z dążenia Greków do charakterystyki istoty (essence) zjawisk, z poszukiwania ogólnych zasad, rządzących światem, z których dałoby się wyprowadzić wszelkie na temat świata ustalenia.

Jako wyraziste przykłady posługiwania się pojęciem istoty w matematyce autorzy podają rozważania algebraiczne. Abstrakcyjne struktury algebraiczne posiadają wielorakie - chciałoby się rzec bardziej konkretne - realizacje. Dla przykładu, struktura trójelementowej przemiennej grupy addytywnej widoczna jest w konkretnych strukturach arytmetycznych (dodawanie modulo 3), geometrycznych (stosowna grupa obrotów), bądź jeszcze innych. To, zdaniem autorów, kolejna ważna metafora matematyki: istota systemu matematycznego to jego struktura algebraiczna.

Logikom XIX wieku (De Morgan, Boole) autorzy przypisują posługiwanie się metaforą: klasy to pojemniki, a następnie wykorzystaniem tego, że liczby (oraz pewne prawa arytmetyczne) dają się przekształcić (metaforycznie) na klasy (oraz pewne operacje na nich). Dalej, metafora Boole'a miałaby polegać na przeniesieniu zależności algebraicznych na zależności w elementarnym rachunku klas (zbiorów), a przyporządkowanie klasom stanów świata sądów (w których sądy owe są prawdziwe) miałaby pozwalać na wykształcenie rachunku zdań. Pewne proste prawa rachunku zdań znajdują przy tym swoje odzwierciedlenie w zasadach dotyczących operowaniem pojemnikami (prawa: wytaczonego środka, modus ponens, modus tollens, sylogizmu hipotetycznego).

Uwagi dotyczące teorii mnogości są raczej skromne. Autorzy wskazują m.in. na:

1. metaforę (pochodzącą od von Neumanna) traktowania liczb naturalnych jako zbiorów;

2. metaforę Cantora, pozwalającą - w terminach relacji równoliczności - porównywać moce zbiorów; 
3. interpretację zbiorów jako grafów, z rozróżnieniem zbiorów spełniających bądź nie aksjomat ufundowania.

Autorzy nie uwzględniają ważnego aksjomatu teorii Zermela-Fraenkla, a mianowicie aksjomatu zastepowania. Jak wiadomo, bez tego aksjomatu nie można wykonać wielu podstawowych operacji w teorii mnogości. W pewnym sensie, aksjomat zastępowania jest również swoistym aksjomatem nieskończoności. Wykorzystywany jest w definicjach przez indukcje pozaskończonq. Nie potrafimy wskazać powodu, dla którego autorzy go pominęli. Można chyba zbudować stosowną metaforę, oddającą sens tego aksjomatu; w uproszczeniu chodzi przecież o to, że obraz zbioru względem funkcji także jest zbiorem.

\section{Ucieleśnienie nieskończoności}

\subsection{Podstawowa metafora nieskończoności}

Procesy w ogólności ujmowane są w terminach metafory pojęciowej, wedle której są one ruchami, za czym kognitywiści argumentowali już wcześniej. Ponadto, ciągłe procesy, bez wyraźnego zaznaczenia ich zakończenia ujmowane są jako (dyskretne) procesy powtarzalne. W przypadku doświadczenia potocznego wskazywać na to ma m.in. zróżnicowanie gramatycznej kategorii aspektu w językach etnicznych. Autorzy piszą (Lakoff, Núñez 2000: 157):

Why is this metaphor important for infinity? The reason is that we commonly apply it to infinitely continuous processes. Continuous processes without end - infinite continuous processes - are conceptualized via this metaphor as if they were infinite iterative processes, processes that iterate without end but in which each iteration has an endpoint and a result. For example, consider infinitely continuous motion, which has no intermediate endpoints and no intermediate locations where the motion stops. Such infinitely continuous motion can be conceptualized metaphorically as iterated motion with intermediate endings to motion and intermediate locations - but with infinitely many iterations.

This metaphor is used in the conceptualization of mathematics to break down continuous processes into infinitely iterating step-by-step processes, in which each step is discrete and minimal. For example, the indefinitely continuous process of reaching a limit is typically conceptualized via this metaphor as an infinite sequence of welldefined steps. 
Wprowadzanie do rozważań matematycznych obiektów infinitarnych jest wedle autorów - ściśle związane z podstawową metaforą, każącą „uzupełnić” powtarzalny process, z nieokreśloną liczbą owych powtórzeń, przez ostateczny wynik takiego procesu. Ten ostateczny wynik to nowy obiekt, mający cechy nieskończoności aktualnej. Hipoteza autorów jest następująca (Lakoff, Núñez 2000: 158):

We hypothesize that all cases of actual infinity - infinite sets, points at infinity, limits of infinite series, infinite intersections, least upper bounds - are special cases of a single general conceptual metaphor in which processes that go on indefinitely are conceptualized as having an end and an ultimate result. We call this metaphor the Basic Metaphor of Infinity, or the BMI for short. The target domain of the BMI is the domain of processes without end - that is, what linguists call imperfective processes. The effect of the BMI is to add a metaphorical completion to the ongoing process so that it is seen as having a result - an infinite thing.

Autorzy odnajdują tę podstawową metaforę w wielu konstrukcjach, omawianych w dalszych rozdziałach. Miałaby ona ingerować we wszelkich sytuacjach, gdy dokonujemy w matematyce jakiegoś przejścia do granicy, zastosowania jakiejś zasady domknięcia, a także gdy korzystamy z zasady indukcji matematycz$n e j$.

\subsection{Liczby rzeczywiste i granice}

Wspomnianą wyżej podstawową metaforę nieskończoności wykorzystują autorzy w wielu przypadkach szczególnych, m.in.:

1. nieskończone rozwinięcia dziesiętne,

2. granice ciągów nieskończonych,

3. szeregi nieskończone (oraz ich sumy),

4. granice funkcji,

5. kresy górne i dolne,

6. przekroje nieskończonych rodzin przedziałów zstępujących. 
$\mathrm{W}$ istocie są to wszystko - naszym zdaniem - próby wskazania na obecność pewnych prawidłowości w procesie tworzenia pojęć matematycznych, gdy chcemy (lub musimy) wprowadzać nowe obiekty, które nie powstają poprzez skończony jedynie ciąg operacji. Autorzy twierdzą, że liczby rzeczywiste tworzone są - różnymi sposobami - z wykorzystaniem BMI. Wzajemnie jednoznaczne odpowiedniości pomiędzy wytworzonymi owymi różnymi sposobami obiektami pozwalają matematykom - wedle opinii autorów - na mówienie o jednej strukturze: the real numbers. W konkluzji rozdziału dodają jednak, że właściwie nie jest wcale oczywiste, iż liczby rzeczywiste musiałyby być tworzone z użyciem tej lub innej wersji BMI.

\subsection{Liczby pozaskończone}

Uwagi tego rozdziału są dość skromne. Przypomina się metodę przekątniową Cantora. Przywołuje się nieco propedeutycznych uwag na temat liczb porządkowych i kardynalnych. Czytelnik nieobeznany z teorią mnogości może odnieść wrażenie, że kolejne moce nieskończone definiowane są w niej poprzez konstrukcje: zbioru potęgowego oraz sumy rodziny zbiorów. Tak rzecz jasna nie jest: skala alefów wprowadzana jest na innej drodze (z wykorzystaniem przyporządkowania Hartogsa). Liczby kardynalne są poczatkowymi liczbami porządkowymi. Odpowiedniość między skalą alefów a skalą mocy zbiorów tworzonych kolejno z jakiegoś zbioru nieskończonego (którego istnienie gwarantuje aksjomat nieskończoności) poprzez iterowanie operacji brania zbioru potęgowego (kroki następnikowe) oraz operacji brania sumy (kroki graniczne) nie jest, jak wiadomo, ustanowiona przez aksjomatyczną teorię mnogości Zermela-Fraenkla: uogólniona hipoteza kontinuum jest od aksjomatów tej teorii niezależna.

Wydaje się, że to nie tylko BMI dostarcza „mechanizmu” dla tworzenia Cantorowskiej skali nieskończoności. Sądzimy, że warto byłoby w tym kontekście wspomnieć o innej jeszcze idei, uważanej za podstawową w Cantorowskiej teorii mnogości, a mianowicie idei ufundowania. To jednak temat na osobną dyskusję.

\subsection{Wielkości nieskończenie małe}

Ten z kolei rozdział jest dość rozbudowany. Autorzy piszą o nieskończenie małych, wprowadzonych do rachunku różniczkowego i całkowego przez Leibniza (właściwie uczynionych przez nich „bardziej znanymi” w ich sformułowaniu). Twierdzą, że zarówno Newton, jak i Leibniz stosowali metaforę: zmiana chwilowa to zmiana średnia wzgledem nieskończenie małego przedziału. Metafora ta wymaga jeszcze - aby wykonalne były rachunki - jakiejś arytmetyzacji owego pojęcia nieskończenie mały. Tu Newton i Leibniz się różnią. Pochodna funkcji dla danego argumentu liczbowego u Newtona to styczna do wykresu funk- 
cji w punkcie, którego odciętej przyporządkowano ową wartość liczbową. Z kolei sama styczna jest granicznym położeniem siecznej. Brane pod uwage odcinki siecznej, gdy przyrost argumentu $\Delta x$ stawał się dowolnie mały miały jednak zawsze określoną długość - można było im przyporządkować pewną liczbę. Różnica długości odcinka siecznej do długości odpowiedniego odcinka stycznej była zatem także zawsze określona liczbowo. Przy dowolnie małym przyroście argumentu różnica ta wyrażała się arytmetyczną funkcją argumentu $\Delta x$. Jeśli wartość tej funkcji stawała się dowolnie mała, to można ją było ignorować i w ten sposób rachunek na długościach siecznych mógł służyć za wystarczająco dobre przybliżenie, wyznaczające styczną. U Newtona mamy więc przejście graniczne w odniesieniu do obiektów geometrycznych.

Inaczej u Leibniza - wprowadza on nieskończenie małe jako wielkości czysto arytmetyczne, jako samoistnie istniejace obiekty matematyczne. Gdy odcinki siecznych u Newtona mają długości, będące liczbami rzeczywistymi, to długości owe u Leibniza wyrażone są liczbami nieskończenie małymi. Geometryczne ujęcie Newtona zyskało solidny grunt arytmetyczny dopiero w wieku XIX, z chwila arytmetyzacji analizy. W analizie matematycznej uprawianej wedle standardu ustanowionego przez Weierstrassa nie było miejsca na nieskończenie małe Leibniza. $\mathrm{Na}$ ich precyzyjny opis matematyczny poczekać musieliśmy do prac Abrahama Robinsona z połowy wieku XX, ustanawiających podstawy analizy niestandardowej. W opisie tym wykorzystuje się konstrukcję ultraproduktu. Liczby hiperrzeczywiste otrzymujemy jako ultraprodukt $\mathbb{R}^{\mathbb{N}} / U$, gdzie $\mathbb{R}$ jest zbiorem wszystkich liczb rzeczywistych, $\mathbb{N}$ zbiorem wszystkich liczb naturalnych, a $U$ ultrafiltrem niegłównym w rodzinie $\wp(\mathbb{N})$ wszystkich podzbiorów zbioru $\mathbb{N}$. To znana konstrukcja, pochodząca w ogólności od Łosia. W pewnym sensie antycypował ją też Skolem, budując swój niestandardowy model arytmetyki.

Autorzy nie przedstawiają szczegółowo tej konstrukcji. Trudno czynić im z tego powodu zarzuty, gdyż precyzyjny opis konstrukcji ultraproduktu wymaga wprowadzenia szeregu pojęć dodatkowych. Ciekawa jednak mogłaby być próba ujęcia tego typu rozumowań $w$ ramach podejścia propagowanego w książce. Trzeba byłoby w tym celu znaleźć odpowiednie metafory dla konstrukcji, oddających ideę równości prawie wszędzie. Takie konstrukcje występują powszechnie w matematyce - nie tylko we wspomnianym przypadku ultraproduktów, ale również np. w teorii miary, w analizie funkcjonalnej, teorii prawdopodobieństwa, itd.

Zamiast tego, autorzy starają się w popularny sposób przedstawić coś, co nazywają liczbami ziarnistymi (granular numbers). Ma to być - jak się zdaje - oswojenie czytelnika z intuicjami związanymi z wprowadzaniem wielkości (liczb) nieskończenie małych. Po uwagach dotyczących twierdzenia o zwartości (w wersji semantycznej) autorzy starają się je wykorzystać dla intuicyjnego wprowadzenia pierwszej liczby nieskończenie małej $\delta$, odwołując się przy tym, rzecz jasna, do swojej ulubionej BMI, podstawowej metafory nieskończoności (zakłada się też, 
iż spełnione są aksjomaty dla liczb rzeczywistych):

1. Niech $x$ będzie dodatnia i mniejsza od 1 .

2. Niech $x$ będzie dodatnia i mniejsza od $\frac{1}{2}$.

3. Niech $x$ będzie dodatnia i mniejsza od $\frac{1}{3}$.

4. Niech $x$ będzie dodatnia i mniejsza od $\frac{1}{4}$.

5. ...

6. W kroku granicznym, niech $\delta$ będzie liczbą spełniającą wszystkie powyższe warunki. Liczba taka istnieje, na mocy twierdzenia o zwartości, bo dla każdego skończonego układu powyższych formuł istnieje liczba czyniąca zadość wszystkim warunkom wyrażonym w formułach tego układu.

Następnie oswajani zostajemy z $H$, liczbą nieskończenie duża, określoną jako $\frac{1}{\delta}$. Potem otrzymujemy nieskończenie małe i nieskończenie duże różnych rzęów, poprzez operacje arytmetyczne (w szczególności, potęgowanie). Autorzy dodają explicite, że owe nieskończenie małe oraz nieskończenie wielkie liczby odnajdujemy w innym, różnym od standardowego, modelu teorii liczb rzeczywistych (oraz całego nieskończonego układu powyżej wyliczonych formuł).

\section{Program dyskretyzacji matematyki}

\subsection{Punkty i kontinuum}

Autorzy zwracają uwagę na dwa sposoby pojęciowego ujmowania przestrzeni $\mathrm{w}$ matematyce. Pierwsze $\mathrm{z}$ nich wiążą z naturalnym pojmowaniem przestrzeni, takim, jakie prawdopodobnie akceptujemy wszyscy w doświadczeniu potocznym. Tu przestrzeń jawi się jako absolutnie ciagła (podobnie płaszczyzna). Nie składa się ona z żadnych obiektów, a raczej jest jakby ttem, na którym obiekty są umieszczane. Linie proste oraz krzywe są absolutnie ciągłe, jak drogi przebiegane przez poruszający się punkt. Wreszcie, punkty same nie są obiektami, a jedynie lokalizacjami: w przestrzeni, na płaszczyźnie, na prostej. $\mathrm{Z}$ ostatnimi z tych pojęć wiążemy intuicyjne pojęcie wymiaru.

To „naturalne” rozumienie przestrzeni zaczyna się zmieniać, piszą autorzy, w miare oswajania metafory: liczby to punkty na prostej (a układy liczb odpowiadają punktom na płaszczyźnie i w przestrzeni). Rozwija się tę metaforę w początkach: geometrii analitycznej oraz rachunku różniczkowego. We współczesnej matematyce autorzy zauważają intensywny rozwój programu jej dyskretyzacji, rozpoczętego w wieku XIX, do realizacji którego przyczyniły się: 
1. Program arytmetyzacji analizy, który miał na celu m.in. wyeliminowanie „naturalnego" rozumienia pojęcia przestrzeni ciągłej i zastąpienie go reprezentacją arytmetyczną.

2. Program formalizacji, który zmierzał do ujęcia matematyki jako manipulacji dyskretnymi symbolami.

3. Logika symboliczna, która miała reprezentować rozumowania na drodze dyskretnej, z wykorzystaniem dyskretnych symboli.

4. Logicyzm, który zamierzał zredukować matematykę do logiki symbolicznej oraz teorii mnogości.

5. Topologia ogólna, która proponowała zastąpienie wspomnianego „,naturalnego" rozumienia pojęcia ciągłej przestrzeni przez rozumienie oparte na pojęciach teorii mnogości.

Współcześnie przestrzeń (płaszczyzna, prosta) pojmowana jest więc jako zbiór, którego elementami są punkty. Rozmyślając nad ewolucją rozumienia pojęcia przestrzeni trzeba pamiętać, że - powiedzmy - dwieście lat temu rozumienie to było inne, było właśnie owym ,naturalnym” rozumieniem. Od XIX wieku w matematyce rozważa się jednak wiele różnorodnych przestrzeni - nie mamy przy tym na myśli jedynie włączenia do tych rozważań geometrii nieeuklidesowych. Ważne uogólnienia podał Riemann - prowadzą one do pojęcia rozmaitości. Topologia ogólna wypracowała całkiem ogólne pojęcie przestrzeni, której bardzo szczególnym przypadkiem jest znana ze szkoły przestrzeń kartezjańska. Dysponujemy ogólnymi pojęciami: metryki oraz normy, i tutaj również np. znana ze szkoły metryka wyznaczona przez miarę odcinka (przez wartość bezwzględną) jest tylko szczególnym przypadkiem. Rozważamy przestrzenie, których elementami mogą być dość skomplikowane twory matematyczne, poczynając, powiedzmy, od funkcji. Analiza funkcjonalna dostarcza środków do badania przestrzeni funkcyjnych oraz operatorów określonych na takich przestrzeniach. Trudno obecnie wyobrazić sobie inny niż teorio-mnogościowy (lub teorio-kategoryjny) paradygmat, w którym jednolicie dałoby się opisać tak różnorodne przestrzenie.

Autorzy starają się eksplikować rozumienie pojęcia punktu przy użyciu BMI, podstawowej metafory nieskończoności - np. w zastosowaniu do zstępującego ciągu dysków o coraz mniejszych średnicach. Przywołują w tym kontekście ewentualność uwzględnienia dysków o średnicach będących liczbami nieskończenie małymi. Wskazują na pewne trudności, które mogą pojawiać się, gdy pytamy np. co miałoby znaczyć, że punkty się stykaja.

Uwagi autorów na temat współczesnego rozumienia takich pojęć jak np. punkt warto może uzupełnić spostrzeżeniem, że możemy też kultywować takie rozumienie pojęć przestrzennych, w których wyjściowymi pojęciami byłyby np. obszary, 
a punkty stawały by się wtedy (być może wysoce skomplikowanymi) konstrukcjami. W istocie, jest to podejście obecne w różnych koncepcjach mereotopologicznych.

Nie kryjąc swoich emocji, autorzy z naciskiem podkreślają istotne różnice pomiędzy „,naturalnym” rozumieniem ciągłej przestrzeni a rozumieniem odwołującym się do programu dyskretyzacji, w którym przestrzeń jest zbiorem, a jego elementami są punkty. Przywołują w tym miejscu m.in. znane przykłady „funkcji wypełniających przestrzeń" (dokładniej: kwadrat jednostkowy), które - przy rozumieniu ,naturalnym” wcale, wedle ich sformułowania, takiej własności wypełniania nie mają.

Za ważne i trafne uważamy następujące uwagi autorów, podane w zakończeniu tego rozdziału (Lakoff, Núñez 2000: 290):

The passion for closure pushed the mathematical community to find all the linearly ordered numbers that could be solutions to polynomial equations - that is, the system of all linear numbers closed under the operations of addition and multiplication, including all the limits of sequences of such numbers.

The principle of closure then had another effect. It tended to keep the mathematical community from looking further at ordered number systems that were not required for closure - systems such as hyperreals. Though infinitesimals were used successfully in mathematics for hundreds of years, the drive for closure of a linear number system led mathematicians to stop with the reals. Closure took precedence over investigating the infinitesimals.

Achieving closure for the real numbers meant "completing" the integers and the rationals. Since numbers were seen as points on the line, that meant "completing" the line - the entire "continuum", finding a "real" number for every possible point. The cardinality of the real numbers - the numerical "size" as measured by Cantor's metaphor became the "number of points on the line". And the Continuum hypothesis, which is about numbers, was thought of as being about points constituting the naturally continuous line.

What was hidden was that "completeness" - closure with limit points - under the discretization program wound up defining what a "point" on a "line" was to be.

Te uwagi autorów należy jednak, naszym zdaniem, skonfrontować także z następującymi ustaleniami samej matematyki: 
1. Wyniki dotyczace możliwych wartości mocy kontinuum. Potęgowanie liczb kardynalnych to bardzo trudna operacja, w teorii mnogości podano jednak szereg twierdzeń ją charakteryzujących (Tarski, Easton, Silver, Shelah,... ). Jeszcze w naiwnej teorii mnogości, przed aksjomatyzacją, udowodniono (König), że moc kontinuum nie ma przeliczalnej współkońcowości. Jak wynika z ustaleń teorii mnogości, kontinuum może przybierać prawie całkiem dowolną wartość na skali alefów. Nie jest więc tak - jak mogłoby zdawać się laikowi po lekturze tego rozdziału - iż matematycy nie są świadomi owej dowolności wartości mocy kontinuum. Osobną kwestią jest oczywiście to, czy ta dowolność przekłada się na to, co autorzy piszą o ,naturalnym” rozumieniu pojęcia przestrzeni ciągłej.

2. Twierdzenia o izomorfizmie. Uwagi autorów o „zasadzie domknięcia” mogą wydać się nieco zwodnicze. Istotnie, matematycy badali struktury domknięte na operacje arytmetyczne (dodawanie, odejmowanie, mnożenie, dzielenie) - badania te zawierają teorie: pierścieni oraz ciat. W szczególności, otrzymano twierdzenia (Frobenius, Hurwitz, Ostrowski, Pontriagin,... ) charakteryzujące, z dokładnością do izomorfizmu te algebry z dzieleniem, w których owe podstawowe operacje arytmetyczne są wykonalne. Twierdzenia te biorą pod uwagę powiązanie własności: arytmetycznych, porządkowych oraz topologicznych. Wyróżniają algebry: liczb rzeczywistych, liczb zespolonych, kwaternionów oraz oktonionów, przy czym tylko w dwóch pierwszych mnożenie jest przemienne (a mnożenie oktonionów nie jest nawet łączne). Liniowo uporządkowane jest ciało liczb rzeczywistych - w ciele liczb zespolonych nie można wprowadzić porządku zgodnego z działaniami arytmetycznymi. Bada się również ciała niearchimedesowe - $\mathrm{np}$. ciała liczb $p$-adycznych, gdzie $p$ jest liczbą pierwszą. Wreszcie, bada się też inne jeszcze struktury, w których współwystępują własności arytmetyczne, porządkowe oraz topologiczne - np. liczby hiperrzeczywiste (o których autorzy wspominają), liczby superrzeczywiste. Liczby nieskończenie małe to pojawiają się $\mathrm{w}$ rozważaniach matematycznych, to z nich znikają, by potem $\mathrm{w}$ innej postaci, w innej szacie matematycznej - znowu się pojawić. Nieskończenie małe w analizie niestandardowej badane są intensywnie dopiero od około pół wieku, trudno przewidzieć, jak intensywny będzie rozwój tej dyscypliny. Istotnie, ze względu na wielość zastosowań najbardziej popularne jest reprezentowanie „kontinuum liniowego” przez zupełne ciało uporządkowane liczb rzeczywistych. To, czy wspomniane kontinuum uzyska powszechnie akceptowane wśród matematyków inne reprezentacje zależy, naszym zdaniem, od tego, jakie ciekawe i ważne w zastosowaniach konsekwencje ujawnią się w tych reprezentacjach. Nie jest to perspektywa kilku, kilkunastu czy nawet kilkudziesięciu lat - zwróćmy uwagę, że do pełnego 
„oswojenia” liczb rzeczywistych w matematyce, do podania pierwszych wystarczająco precyzyjnych definicji, potrzeba było około dwóch tysięcy lat.

\subsection{Ciagłość dla liczb: metafora Dedekinda}

Konstrukcję Dedekinda liczb rzeczywistych uważają autorzy za jeden z ważniejszych momentów w historii współczesnej matematyki. Jak wiadomo, podano różne definicje (można wyliczyć bodaj dwanaście najważniejszych) pojęcia liczby rzeczywistej. Zwykle przywołuje się w podręcznikach jedną z dwóch definicji: Cantora (liczby rzeczywiste jako klasy abstrakcji stosownej relacji równoważności między ciągami Cauchy'ego) lub Dedekinda (liczby rzeczywiste jako przekroje zbioru liczb wymiernych).

Konstrukcję Dedekinda autorzy chcą oczywiście zaprezentować jako wynik zastosowania szczególnych metafor. Mówią więc o: metaforze przekroju geometrycznego Dedekinda oraz metaforze przekroju arytmetycznego Dedekinda. Cytują wybrane fragmenty Stetigkeit und irrationale Zahlen, przywołują intuicje związane z ludowq teoriq mierzenia $i$ wielkości (The Folk Theory of Measurement and Magnitude), a konstrukcję Dedekinda podsumowują następująco (Lakoff, Núñez 2000: 302):

In short, the Dedekind Arithmetic Cut metaphor states: A real number is an ordered pair of sets $(A, B)$ of rational numbers, with all the rationals in $A$ being less than all the rationals in $B$, and all the rational numbers are in $A \cup B$.

Dodają również, że wspomniane metafory Dedekinda wzięte łącznie ukazują, że przekroje liczb wymiernych wyczerpują ogół liczb rzeczywistych, i w szczególności eliminują z analizy nieskończenie małe. Argumentują następująco:

1. Metafora przekroju geometrycznego Dedekinda (wykorzystująca Rame Pojeciowa Przekroju, Dedekind's Cut Frame - będącą metaforą linia liczb wymiernych wraz z punktem $C$ na tejże linii, dzielącym wszystkie liczby wymierne na rozłączne zbiory $A$ i $B$, gdzie wszystkie liczby w $A$ są mniejsze od wszystkich liczb w $B$ ) polega na przyporządkowaniu tej ramie, w dziedzinie docelowej, połączenia metaforycznego linia liczb rzeczywistych wraz ze wspomnianą ramą.

2. Dedekind ma zakładać istnienie liczby rzeczywistej dla każdego punktu prostej. Daje to podstawę dla Measurement Criterion for Completeness liczb rzeczywistych. 
3. Powyższe kryterium zakłada, wedle autorów, połączenie metaforyczne liczby to punkty na linii oraz aksjomat Archimedesa.

4. Z ostatnich dwóch założeń wynika jednoznaczność konstrukcji każdej liczby rzeczywistej.

5. Arytmetyczna metafora przekroju gwarantuje, że w zbiorze liczb rzeczywistych zdefiniowanych przez Dedekinda nie ma żadnych luk (gaps).

6. Tak więc, przekroje liczb wymiernych wyczerpują ogół liczb rzeczywistych.

7. Wreszcie, ciągłość prostej rzeczywistej miałaby być gwarantowana metaforą: Continuity for the Number Line Is Arithmetic Gaplessness.

Przyznajemy, że nie we wszystkim potrafimy nadążyć za argumentacją autorów. W szczególności, trudno nam się zgodzić, aby najważniejsze w konstrukcji Dedekinda było jego rzekome inspirowanie się pojęciami geometrycznymi. Wydaje się, że należałoby raczej zwrócić uwagę na następujące sprawy:

1. Istotnie, Dedekind chciał wyeliminować z mówienia o liczbach rzeczywistych wszelkie intuicyjne odniesienia geometryczne. Na drugim niejako planie wskazywał na możliwość ustalenia wzajemnie jednoznacznej odpowiedniości między skonstruowanymi liczbami rzeczywistymi a punktami prostej rzeczywistej.

2. Dedekind podaje dowód, że rodzina wszystkich przekrojów liczb wymiernych, ze stosownie zdefiniowanym porządkiem tych przekrojów ma własność ciagłości, w tym sensie, iż porządek ten nie zawiera luk.

3. Dedekind pokazuje, że w zbiorze wszystkich przekrojów liczb wymiernych określić można działania arytmetyczne. Współcześnie dodamy: operacje arytmetyczne zgodne z porządkiem. Liczby rzeczywiste Dedekinda tworzą więc ciało uporządkowane w sposób ciągły.

4. Każde ciało uporządkowane w sposób ciągły jest archimedesowe.

5. Dedekind pokazuje, że liczby wymierne tworzą ośrodek w zbiorze liczb rzeczywistych.

6. Gdy rozważymy liczby hiperrzeczywiste ze standardowo definiowanym dla nich porządkiem $\left(\mathbb{R}^{*},<_{U}\right)$ (gdzie $U$ jest używanym w konstrukcji ultrafiltrem niegłównym), to można zauważyć, że: 
(a) Rodzina $\mathcal{R}^{*}$ wszystkich przekrojów zbioru $\left(\mathbb{R}^{*},<_{U}\right)$ jest ciągła w sensie Dedekinda.

(b) Ani $\left(\mathbb{R}^{*},<_{U}\right)$ ani rodzina $\mathcal{R}^{*}$ tych przekrojów nie jest przestrzenią ośrodkową.

(c) W konsekwencji, żadna z tych struktur nie jest izomorficzna ze standardowo uporządkowanym zbiorem liczb rzeczywistych $(\mathbb{R},<)$.

(d) Liczby nieskończenie małe są domknięte na dodawanie i mnożenie (tworzą pierścień). Jednak w zbiorze wszystkich przekrojów struktury $\left(\mathbb{R}^{*},<_{U}\right)$ nie można określić działań arytmetycznych tak, aby uzyskać strukturę ciała. Gdy bowiem rozważyć przekrój $(A, B)$ taki, że $A$ to wszystkie ujemne liczby hiperrzeczywiste oraz liczby nieskończenie małe, a $B$ to reszta liczb hiperrzeczywistych, to widać, iż przekrój ten wyznacza lukę. Zgodnie $\mathrm{z}$ definicją proponowaną dla przekrojów powinno być:

$$
\begin{aligned}
& (A, B)+(A, B)=(A, B) \\
& (A, B) \times(A, B)=(A, B),
\end{aligned}
$$

a więc nie otrzymujemy ani grupy addytywnej ze względu na dodawanie, ani grupy multiplikatywnej ze względu na mnożenie.

(e) Nauka z tego m.in. taka (por. (Błaszczyk 2007: 183), (Batóg 2000: 30-31)), że uzupełnianie zbioru uporządkowanego metodą Dedekinda jest w samej swojej istocie rozszerzaniem ciata (liczb wymiernych), a nie po prostu ,wypełnianiem luk w porządku” nowymi elementami.

7. Dedekind wykonał przede wszystkim pewną (znakomitą!) robotę algebraiczną. Pokazał zarówno metodę konstrukcji pewnej specjalnej struktury arytmetyczno-porządkowej (liczb rzeczywistych właśnie), ale także dał podstawy pod tzw. metode uzupetniania Dedekinda, powszechnie wykorzystywaną w teorii struktur porządkowych, topologii, itd.

8. Dedekind wskazał na możliwość interpretacji ciagłości prostej rzeczywistej w terminach arytmetycznych. Przy tym, owa prosta rzeczywista była obiektem dość tajemniczym - w systemie geometrii Euklidesa nie występują proste (są jedynie odcinki, które można dowolnie przedłużać). Jeśli więc mówić o jakiejś metaforze Dedekinda, to należałoby chyba odnosić ją do ukazanej przezeń odpowiedniości pomiędzy zdefiniowanymi przez niego (z uwzględnieniem własności arytmetycznych i porządkowych) liczbami rzeczywistymi a wielkościami geometrycznymi wiązanymi tradycyjnie z odcinkami. 
9. Dedekind operował zbiorami oraz liczbami wymiernymi (oraz porządkiem i operacjami arytmetycznymi na nich), lecz nie dysponował jeszcze ani teorią zbiorów (tej dostarczył później Cantor, a w postaci aksjomatycznej ugruntował Zermelo), ani teorią liczb wymiernych (tę z kolei podał Weber). Teorię liczb wymiernych wreszcie oprzeć można było na aksjomatycznej teorii liczb naturalnych, którą opracował Peano.

10. Na marginesie dodajmy jeszcze, że aksjomat ciągłości jest niezależny od aksjomatów geometrii absolutnej. Istnieją modele tej geometrii, w których aksjomat ten nie zachodzi.

Tak więc, proste metafory przekroju (geometryczna i arytmetyczna, w terminologii autorów) to jeszcze nie wszystko, jeśli chodzi o analize idei matematycznych związanych z konstrukcją Dedekinda. Wnikliwą analizę konstrukcji Dedekinda, wraz z wieloma odniesieniami do innych konstrukcji liczb rzeczywistych zawiera monografia (Błaszczyk 2007). Niezwykle interesujące uwagi dotyczące rozumienia pojęcia ciągłości w matematyce znajdujemy np. w (Mioduszewski 1996).

Autorzy oczywiście trafnie podkreślają, że swoją konstrukcją Dedekind uwolnił podstawy analizy od konieczności odwoływania się do rozumienia ciągłości jako np. jakoś wyznaczonej przez ruch punktu. Trafnie też zwracają uwagę na fundamentalną - z filozoficznego punktu widzenia - rolę następującego fragmentu rozprawy Dedekinda ((Dedekind 1872: 11), przekład - JP):

Przyjęcie tej własności linii prostej jest niczym innym jak aksjomatem, dopiero na mocy którego przyznajemy linii prostej jej ciaggłość, na mocy którego wnikamy w ciągłość linii prostej. Jeśli przestrzeń ma w ogóle jakąś realną egzystencję, to wcale nie musi koniecznie być ciągła; niezliczone jej własności pozostałyby takie same, gdyby była nieciągła. I gdybyśmy wiedzieli z pewnością, że przestrzeń jest nieciągła, to i tak nic nie mogłoby nas powstrzymać, gdybyśmy tego chcieli, aby w myśli uczynić ją ciągłą, poprzez wypełnienie jej luk; to wypełnienie polegałoby jednak na tworzeniu nowych indywiduów punktowych wedle powyższej zasady.

Również twórcy innych definicji liczb rzeczywistych (Hilbert, Cantor, Heine) przyznawali, iż nie ma żadnych dowodów na to, że przestrzeń (fizyczna) ma naturę ciągłą. Algebraiczna konstrukcja liczb rzeczywistych Dedekinda to przykład swobody twórczej matematyki. Innym takim przykładem, znanym każdemu, kto choć trochę interesuje się matematyką jest konstrukcja skali alefów w teorii mnogości. Można szukać - w różnych działach matematyki - dalszych przykładów 
takiej wolnej kreatywności. Ciekawym problemem może okazać się to, czy istotnie wszelkie tego typu przykłady można eksplikować wedle schematu tworzenia metafor, proponowanego przez Lakoffa i Núñeza.

\subsection{Analiza bez przestrzeni i ruchu: ujęcie Weierstrassa}

Program arytmetyzacji analizy miał nadać wszelkim rozważaniom w tej dyscyplinie cechy ścisłości, pozbawić je jakichkolwiek odwołań do intuicji. Wielu matematyków przyczyniło się do realizacji tego programu, lecz za najważniejsze uważa się powszechnie osiągnięcia Weierstrassa.

\subsection{Arytmetyzacja analizy}

Postanowiono wyeliminować z analizy wszelkie intuicyjne odwołania do geometrii, określić takie pojęcia jak: granica, ciągłość funkcji, pochodna, całka wyłącznie w terminach liczbowych. Autorzy piszą, że zgodnie z zaleceniami tego programu:

1. „Naturalne” rozumienie ciągłości miało zostać wyeliminowane z rozumienia pojęć: przestrzeni, płaszczyzny, prostych, krzywych, figur geometrycznych. Geometria miała być ujmowana w terminach zbiorów dyskretnych punktów, a te z kolei miały być ujmowane jako liczby bądź ich układy.

2. Pomysł uważania krzywej jako wyniku ruchu punktu miał zostać porzucony. Żadnych odwołań do ruchu, upływu czasu, ,,zbliżania się”, itp. Wszystkim tym sformułowaniom należało nadać szatę liczbową.

Oznaczało to istotną zmianę myślenia o matematyce, wymagało rektyfikacji pojęć matematycznych. Przyjęte rozwiązania tych problemów są akceptowane także dzisiaj. Przypomnijmy:

1. Granica funkcji. Niech $f$ będzie funkcją zdefiniowaną na przedziale otwartym zawierającym liczbę $a$ oraz niech $b$ będzie liczbą rzeczywistą. Mówimy, że $b$ jest granicą funkcji $f$ w punkcie $a$, co zapisujemy $\lim _{x \rightarrow a} f(x)=b$, gdy dla każdej $\varepsilon>0$ istnieje $\delta>0$ taka, że jeśli $0<|x-a|<\delta$, to $|f(x)-b|<\varepsilon$. Przy tym, $f$ może nie być zdefiniowana dla argumentu $a(\mathrm{tj} . f(a)$ może nie mieć wartości będącej liczbą rzeczywistą).

2. Ciagłość funkcji. Funkcja $f$ jest ciagła w punkcie (liczbie) a, gdy:

(a) $f$ jest zdefiniowana w przedziale otwartym zawierającym $a$, 
(b) $\lim _{x \rightarrow a} f(x)$ istnieje,

(c) $\lim _{x \rightarrow a} f(x)=f(a)$.

3. Pochodna funkcji. Przez pochodną $y=f^{\prime}(x)$ funkcji $f$ rozumiemy zbiór par $(x, y)$ takich, że: dla każdego $\varepsilon$-otoczenia $y$ istnieje $\delta$-otoczenie $x$ takie, że $\frac{f(x+\delta)-f(x)}{\delta}$ znajduje się w tym $\varepsilon$-otoczeniu $y$.

Autorzy przypisują Weierstrassowi posługiwanie się BMI, podstawową metaforą nieskończoności, w ustalaniu definicji tych pojęć. Piszą też, że - mimo wszystko - nie udało mu się całkowicie pozbyć odwołań do geometrii. Stosunek odległości do czasu, gdy czas sam jest metaforycznie pojmowany jako odległość, występuje w metaforze Newtona-Leibniza: zmiana chwilowa to stosunek średniej zmiany odległości do nieskończenie małego przedziału czasu. To właśnie ma być oddawane arytmetycznie wyrażeniem $\frac{f(x+\delta)-f(x)}{\delta}$, gdzie $\delta$ dąży do granicy 0 . Autorzy są przekonani, że nie można całkowicie wyrugować w tym kontekście odwołań do geometrii (Lakoff, Núñez 2000: 315):

In these metaphors, there is implicit geometry: the ratio of distance to time, where time is itself conceptualized metaphorically as distance. If mathematics is taken to include the ideas that arithmetic expresses - that is, if calculus is taken to be about something - namely, change then Weierstrass did not eliminate geometry at all. From the conceptual perspective, he just hid it. From the perspective of mathematical idea analysis, no one could eliminate the geometry metaphorically implicit in the very concept of change in classical mathematics.

Osobną jest sprawą, czy powyższe ogólne uwagi autorów są trafne. Czy takie teorie zmiany, które nie wymagają odwołania się do pojęcia czasu są logicznie wykluczone?

\subsection{Oswajanie potworów}

Rozumienie ogólnego pojęcia funkcji ulegało zmianom w matematyce ostatnich stuleci. Gdy w wieku XIX zaczęto dopuszczać mówienie o funkcjach jako całkiem dowolnych zbiorach par uporządkowanych (spełniających oczywisty warunek jednoznaczności), okazało się, że oprócz naturalnych, zgodnych z intuicjami doświadczenia potocznego zależności funkcyjnych za funkcje w tym najbardziej ogólnym znaczeniu musimy uznać również takie zależności, które tym intuicjom dramatycznie przeczą. Autorzy przywołują listę własności uznawanych za „normalne" własności krzywych w przestrzeni trójwymiarowej, sporządzoną pod koniec XIX wieku przez Jamesa Pierponta. Wedle niej krzywa taka: 
1. Może zostać utworzona przez ruch punktu.

2. Jest ciągła.

3. Ma styczną.

4. Ma długość.

5. Jeśli jest zamknięta, to stanowi granicę obszaru, a obszar ten ma pole.

6. Nie jest powierzchnią.

7. Jest utworzona poprzez przecięcie dwóch powierzchni.

Skonstruowano liczne przykłady funkcji (pojmowanej w najbardziej ogólny sposób), które własności tych nie posiadają. Dość dobrze znane są przykłady funkcji wypetniajacych kwadrat jednostkowy (Peano, Hilbert) - powstają one jako granice jednostajnie zbieżnego ciągu funkcji (a więc są ciągłe), lecz nie mają pochodnej w żadnym punkcie (w terminach intuicyjnych powiemy: ich wykres jest „,złamany” w każdym punkcie). Wypełniają one kwadrat jednostkowy, a więc ich wykres jest powierzchnią - to kłóci się z intuicjami przypisującymi krzywej inny wymiar niż powierzchniom. Inny przykład podał Weierstrass:

1. Krzywa Weierstrassa. Był to pierwszy z podanych przykładów funkcji ciągłej, która w żadnym punkcie nie jest różniczkowalna (choć podobno już Bolzano rozważał takie konstrukcje).

$$
f(x)=\sum_{n=0}^{\infty} a^{n} \cos \left(b^{n} \pi x\right)
$$
(a) $0<a<1$
(b) $b$ dodatnia nieparzysta
(c) $a b>1+\frac{3}{2} \pi$.

Autorzy nie przywołują tego przykładu, ale zwracają uwage na pewne inne jeszcze - najbardziej ogólnie rozumiane - funkcje, które też nazywają potworami:

1. Potwór 1. Funkcja określona wzorem: $f(x)=\sin \left(\frac{1}{x}\right)$ dla $x \neq 0$ oraz $f(0)=$ 0 . Nie jest ciągła w sensie Weierstrassa.

2. Potwór 2. Funkcja określona wzorem: $f(x)=x \sin \left(\frac{1}{x}\right)$ dla $x \neq 0$ oraz $f(0)=0$. Jest ciągła w sensie Weierstrassa. 
3. Potwór 3. To omówiona wcześniej krzywa Hilberta.

4. Potwór 4. Funkcja określona wzorem: $f(x)=1$, gdy $x$ jest niewymierna, zaś $f(x)=0$, gdy $x$ jest wymierna. Nie jest ciągła w sensie Weierstrassa.

5. Potwór 5. Funkcja określona wzorem: $f(x)=1$, gdy $x$ jest niewymierna, zaś nieokreślona, gdy $x$ jest wymierna. Jest ciagła w sensie Weierstrassa.

Nietrudno wykryć, które z „prototypowych” własności krzywych wyliczonych przez Pierponta nie przysługują powyższym potworom. We współczesnych podręcznikach analizy lub topologii podaje się całe mnóstwo dalszych przykładów tego rodzaju - por. np. (Gelmbaum, Olmsted 1990, 2003), (Steen, Seebach 1995), (Wise, Hall 1993).

\subsection{Czy można zrozumieć ,ciagłe” w terminach „,dyskretnego”?}

Czy można uznać, że odtąd - po arytmetyzacji analizy w stylu Weierstrassa istota ciagłości jest już w pełni, wyczerpująco dobrze określona? Chyba nie wszyscy matematycy zgodzą się z takim stwierdzeniem - por. np. uwagi kończące książkę (Mioduszewski 1996). Zacytujmy też zdanie kończące znaną książkę dotyczącą struktury prostej rzeczywistej (Bukovský 1979: 206):

Z toho, čo sme uviedli, môžeme však dôjst' k rovnakému poučeniu, aké predpovedal N. Luzin v [59], str. 322: že prišiel čas, ked' je potrebné vykonat' reformu našich predstav́ o kontinuu. [Tutaj [59] odnosi się do pracy: Luzin, N. 1930. Leçons sur les ensembles analytiques. Paris: Gauthier-Villars.]

Lakoff i Núñez przywołują natomiast pewne uwagi Hermanna Weyla z jego rozprawy o kontinuum także wyrażające wątpliwość, czy udało się już adekwatnie opisać istotę ciągłości, a co za tym idzie, strukturę kontinuum. Od siebie piszą zaś (Lakoff, Núñez 2000: 323-324):

Each attempt to understand the continuous in terms of the discrete is necessarily metaphorical - an attempt to understand one kind of thing in terms of another kind of thing. Indeed, it is an attempt to understand one kind of thing - the naturally continuous continuum - in terms of its very opposite - the discrete. We find it strange that it should be seen as a central task of mathematics to provide a metaphorical characterization of the continuum in terms of its opposite. Any such metaphor is bound to miss aspects of what the continuum is, and miss quite a bit. 
If "the great task" is to provide absolute, literal foundations for mathematics, then the attempt to conceptualize the continuous in terms of the discrete is self-defeating. First, such foundations cannot be literal; they can only be metaphorical. Second, as Weyl himself says, only "part of its content" can be conceptualized discretely. The rest must be left out. If Weyl is right, the task cannot be accomplished.

We believe there is a greater task: understanding mathematical ideas.

\subsection{Le trou normand}

Rozważania o samej matematyce oddzielono od rozważań o filozofii matematyki niewielką wstawką, podającą ciekawy paradoks nieskończoności. Narysujmy półokrąg o promieniu $\frac{1}{2}$ oraz środku w punkcie o współrzędnych $\left(\frac{1}{2}, 0\right)$. Długość tego półokręgu wynosi $\frac{\pi}{2}$. Teraz narysujmy dwa półokręgi, każdy o promieniu $\frac{1}{4}$ oraz środkach w punktach o współrzędnych, odpowiednio: $\left(\frac{1}{4}, 0\right)$ oraz $\left(\frac{3}{4}, 0\right)$. Każdy $\mathrm{z}$ nich ma długość $\frac{\pi}{4}$, a więc suma ich długości to $\frac{\pi}{2}$. Iterujemy ten proces, budując w kroku $n$ ciąg półokręgów o promieniu $\frac{1}{2^{n}}$ i środkach w punktach o odciętych, odpowiednio $\frac{1}{2^{n}}, \frac{2}{2^{n}}, \ldots, \frac{n-1}{2^{n}}$ i rzędnej 0 . Każdy z półokręgów utworzonych w kroku $n$ ma długość $\frac{\pi}{2^{n}}$, a więc łącznie daje to sumę ich długości równą $\frac{\pi}{2}$. Co „dzieje się" w granicy? Chciałoby się rzec, zdając się na „zdroworozsądkowe” intuicje: skoro pole ograniczone osią odciętych i krzywą powstającą z połączenia konstruowanych półokręgów (autorzy nazywają tę graniczną krzywą the bumping curve) zmierza do zera, to oś odciętych i owa krzywa stają się dowolnie bliskie. Jednak rozważany odcinek osi odciętych ma długość 1, a rozważana krzywa graniczna ma długość $\frac{\pi}{2}$. Paradoks!

Autorzy objaśniają źródła owego paradoksu, pouczając, jak należy mierzyć odległość w przestrzeniach funkcyjnych. W rozważanym przypadku odległość ta dana jest wzorem:

$$
d(f, g)=\sup _{x}|f(x)-g(x)|+\int_{0}^{1}\left(\left|f^{\prime}(x)-g^{\prime}(x)\right|\right) d x .
$$

Nie bierzemy zatem pod uwage jedynie różnic wartości funkcji, ale także drugi składnik powyższej sumy.

\section{$5 \quad$ Implikacje dla filozofii matematyki}

Niewątpliwie propozycje autorów stanowią novum w rozważaniach nad tworzeniem pojęć matematycznych oraz w analizie idei w matematyce. Należy może raz 
jeszcze powtórzyć: nie są to ani wyniki wewnątrz samej matematyki, ani samoistne refleksje filozoficzne, choć oczywiście można te propozycje konfrontować zarówno z twórczością matematyków, jak i z poglądami filozofów na temat tej twórczości.

\subsection{Teoria ucieleśnionej matematyki}

Autorzy oświadczają wyraźnie, iż są świadomi, że ich propozycje mogą zostać - z różnych powodów, w tym także światopoglądowych - odrzucone przez zawodowych matematyków, zwłaszcza gdy ci ostatni są emocjonalnie i z pełnym przekonaniem przywiązani do tego, co autorzy nazwali we wstępie mitologią matematyki. Lakoff i Núñez przyznają, że owa mitologia posiada walory estetyczne, jest sama w sobie piękna, a nawet - wedle ich własnego określenia - seksowna. Uważają też jednak, że jest ona szkodliwa społecznie, propagując nietrafny obraz matematyki oraz nadając matematykom status, który im się nie należy. Tego ostatniego stwierdzenia nie zamierzamy w tym miejscu komentować.

Autorzy twierdzą, że nie ma żadnego naukowego dowodu na to, że to, czego dowodzimy w ludzkiej matematyce jest uniwersalną prawdą obiektywną, a nawet, że dowód taki w ogóle jest niemożliwy. Jednym z argumentów autorów na rzecz tego, że nie istnieje transcendentna matematyka jest to, że podstawowe obiekty matematyczne - na przykład liczby - są w matematyce opisywane na wiele, wzajem niezgodnych sposobów: liczby to punkty na osi, liczby to zbiory, liczby to wartości pozycji w grach kombinatorycznych, itd. Gdyby istniała transcendentna matematyka, to liczby (oraz inne obiekty matematyczne) musiałyby być ontologicznie precyzyjnie określone, a tak nie jest, zdaniem autorów.

Matematyka nie jest również, ich zdaniem, częścią świata fizycznego, zaś argumenty odwołujące się do ,niewiarygodnej skuteczności matematyki” powinny być właściwie rozumiane. Na to poprawne rozumienie składają się następujące przekonania:

1. W świecie istnieją niezależne od nas regularności.

2. My, ludzie, wymyśliliśmy niesprzeczne oraz trwałe formy matematyki (zazwyczaj dające poprawne odpowiedzi w zastosowaniach).

3. Czasem fizycy odnoszą sukces w dopasowaniu ludzkiej matematyki do swoich - także ludzkich - konceptualizacji regularności obserwowanych w świecie fizycznym. Pojęcia matematyczne nie egzystują jednak w świecie fizycznym.

Jedyną matematyką jest - zdaniem autorów - matematyka ucieleśniona (Lakoff, Núñez 2000: 346-347): 
For human beings - or any other embodied beings - mathematics is embodied mathematics. The only mathematics we can know is the mathematics that our bodies and brains allow us to know. For this reason, the theory of embodied mathematics we have been describing throughout the book is anything but innocuous. As a theory of the only mathematics we know or can know, it is a theory of what mathematics is - what it really is!

Because it is an empirical theory about the embodied mind, the theory of embodied mathematics is framed within the study of embodied cognition. The elements of embodied cognition are not axioms and proofs but image schemas, aspectual concepts, basic-level concepts, semantic frames, conceptual metaphors, conceptual blends, and so on. Because mathematics does not study the mind, it cannot study itself as a product of mind. The methods and apparatus of embodied cognitive science are necessary.

Teoria ucieleśnionej matematyki nie jest i nie może być teorią wewnątrz samej matematyki. Musi jednak czynić zadość wielu wymaganiom charakterystycznym dla nauk kognitywnych w ogólności. Oprócz empirycznych poświadczeń eksperymentalnych teorie $\mathrm{z}$ tych nauk muszą posiadać moc wyjaśniającą - powinny wyjaśniać np. w jaki sposób możemy posiadać pojęcia abstrakcyjne, a co ważniejsze, jak je rozumiemy. Odnosi się to, w naszym przypadku, do wszelkich pojęć matematycznych. Porządna teoria kognitywistyczna powinna wyjaśniać, jak rozumiemy takie pojęcia. Przy tym rozumienie, zdaniem autorów, nie może zostać sprowadzone jedynie do znajomości aksjomatów, twierdzeń, dowodów i do symbolicznego na nich operowania. Poznanie matematyczne powinno być objaśniane m.in. w odwołaniu do mechanizmów poznawczych oraz neuronowych (neural) obecnych w nieświadomym ludzkim systemie pojęciowym. Przypuszcza się, że w przypadku poznania matematycznego istotne są takie same mechanizmy, jak w przypadku każdego innego poznania - autorzy starali się to potwierdzić licznymi przykładami omawianymi wcześniej w tekście.

Poznanie matematyczne musi być objaśniane również w aspekcie historycznym. Zmienia się rozumienie pojęć matematycznych, zmieniają się zainteresowania i mody matematyczne.

Matematyka jest twórczością umysłową wykształconą dla badania obiektów świata zewnętrznego. Takie cechy matematyki, jak: uniwersalność, precyzja, niesprzeczność, stabilność, możliwość dokonywania uogólnień oraz odkryć autorzy wiążą z odpowiednimi własnościami obiektów doświadczenia potocznego.

Teoria ucieleśnionej matematyki, wsparta faktami z historii matematyki oraz wynikami badań szczegółowych czyni, zdaniem autorów, następujące ustalenia: 
1. Matematyka jest produktem ludzkim, zdeterminowanym przez naszą biologię, system pojęciowy oraz czynniki społeczne i kulturowe.

2. Zaawansowana matematyka powstaje jako wynik zdolności poznawczych wspólnych wszystkim ludziom (np. zdolność tworzenia metafor).

3. Proste struktury arytmetyczne są wrodzone.

4. Działy matematyki wyrastają z ludzkich zainteresowań i aktywności.

5. Precyzja w matematyce jest możliwa, ponieważ ludzie są w stanie dokonywać jasnych i dokładnych odróżnień dotyczących obiektów i kategorii. Jest ona ponadto wspierana przez ludzką zdolność symbolizowania.

6. Metafory pojęciowe są podstawowym, neuronalnie ugruntowanym mechanizmem poznawczym.

7. Wnioskowania i obliczenia przeprowadzone w społeczności matematyków nie mają skłonności do zmian w czasie lub między kulturami.

8. Matematyka nie jest monolitem, jeśli chodzi o jej najbardziej podstawowe teorie. Nie ma jednej geometrii, jednej teorii mnogości, jednej logiki formalnej.

9. Matematyka jest skuteczna w charakteryzowaniu różnych aspektów świata oraz w przewidywaniu. Rozwijaliśmy się w taki sposób, że poznanie potoczne dopasowuje nas do świata. Matematyka jest systematycznym rozszerzeniem tego właśnie poznania.

Ponieważ pewne aspekty ludzkiego systemu poznawczego mają walor uniwersalności oraz są wyposażone w takie mechanizmy zachowujące wnioskowania jak np. metafory pojęciowe, więc sama matematyka (przeprowadzane w niej dowody i obliczenia) są trwałe, możliwe są odkrycia bez odwołań do empirii, abstrahowanie, trwałe i naturalne powiązania pomiędzy różnymi działami matematyki oraz systematyczny rozwój matematyki w czasie.

Poznanie matematyczne uważają autorzy za ponadkulturowe, zwracają jednak uwagę, że formy tego poznania sa w pewnym sensie kulturowo uwarunkowane wystarczy wspomnieć greckie przeświadczenia, że zjawiska mają swoją istotę, że przedmiot poznania można i należy ugruntować na jakiejś podstawie, że rozumowania można reprezentować matematycznie w formie systemów logicznych te przeświadczenia przekładają się na wzorzec uprawiania (poszczególnych działów) matematyki w postaci teorii aksjomatycznych. Matematyka w żadnym przypadku nie powinna być rozumiana na modłę postmodernistyczną, jako całkowicie 
dowolnie ukształtowana przez historię i kulturę. To raczej przekonanie o transcendentności matematyki zasługuje, zdaniem autorów, na nazwanie go równie antynaukowym jak radykalny postmodernizm.

\subsection{Filozofia ucieleśnionej matematyki}

Dla pytań o to, czym są obiekty matematyczne oraz czym jest prawda matematyczna (obu w sensie ucieleśnionej matematyki) autorzy podają odpowiedzi w kilku przypadkach szczególnych (liczba zero, zbiór pusty, suma nieskończona, liczba kardynalna $\aleph_{0}$ ). Są to, jak łatwo się domyślić, argumentacje wskazujące na metaforyczne pochodzenie tych obiektów oraz prawdziwości stwierdzeń o nich.

Jeśli chodzi natomiast o tzw. The Formal Reduction Metaphor - metaforę, która przyporządkowuje konstruktom teorio-mnogościowym pojęcia matematyczne, to autorzy dopuszczają tylko jedną jej interpretację, nazywaną przez nich kognitywną. Każe ona operować na pojęciach matematycznych w połączeniu z ich reprezentacjami teorio-mnogościowymi. Autorzy odrzucają natomiast drugą interpretację, wedle której pojęcia matematyczne miałyby być dosłownie redukowane do konstrukcji z teorii mnogości.

Jaki obraz matematyki wyłania się zatem z ustaleń autorów? Twierdzą oni, że udało im się obalić mity dotyczące matematyki, o których wspomniano we wstępie. Ponadto, uważają, że potraktowanie działalności matematyków oraz wyników tych działań może zostać - choćby wstępnie - scharakteryzowane poprzez wszechobecną metaforyzację, dokonywaną przez ucieleśniony umysł. Podsumowują swój portret matematyki następująco (strony 377-379):

1. Matematyka jest naturalnym składnikiem bycia człowiekiem. Wyrasta z naszych ciał, mózgów oraz codziennych doświadczeń. Każda kultura dysponuje jakąś formą matematyki.

2. Matematyka jest przedmiotem badania naukowego, i nie ma w tym niczego magicznego, mistycznego, tajemniczego. Jest konsekwencją ludzkiej historii ewolucyjnej, neurobiologii, zdolności poznawczych oraz kultury.

3. Matematyka jest jednym z największych osiągnięć zbiorowej ludzkiej wyobraźni.

4. Matematyka jest systemem ludzkich pojęć, który czyni niezwykły użytek ze zwykłych środków ludzkiego poznania. Ma takie, wymienione już wcześniej cechy, jak: uniwersalność, precyzja, niesprzeczność, stabilność, możliwość dokonywania uogólnień oraz odkryć.

5. Skuteczność matematyki jest wynikiem ewolucji oraz kultury. Ewolucja wykształciła nasze ciała i mózgi tak, że otrzymaliśmy neuronowe zdolności 
dla reprezentowania podstaw arytmetyki oraz pierwotnych zależności przestrzennych. Kultura pozwoliła, poprzez prowadzone miliony lat obserwacje natury na wykształcenie coraz bardziej skomplikowanych środków matematycznych. Połączenie idei matematycznych oraz ludzkich doświadczeń świata ma miejsce w ludzkim umyśle.

6. Pojęcia doświadczenia potocznego takie jak np.: zmiana, proporcja, wielkość, obrót, prawdopodobieństwo, rekurencja, iteracja oraz setki innych zostały zmatematyzowane - matematyzacja zwykłych ludzkich pojęć jest zwykłym ludzkim wyzwaniem.

7. Rozwój systemów pisma umożliwił też rozwój notacji matematycznej. Metafory dyskretyzacji pozwoliły na precyzyjne ujęcie stale rosnącej liczby pojęć matematycznych. Ludzka zdolność do tworzenia metafor pojęciowych pozwoliła na matematyzację (a czasem nawet arytmetyzację) pojęć potocznych, takich jak: kolekcje, wymiary, symetrie, zależność i niezależność przyczynowa, itd.

8. Wszystko w matematyce daje się - przynajmniej w zasadzie - zrozumieć.

9. Ludzka inteligencja ma wiele aspektów, inteligencja matematyczna to tylko jej część (podobnie jak inteligencja muzyczna, literacka, itd.).

10. Matematyka jest twórcza i otwarta. Wykorzystywać możemy coraz to nowe metafory pojęciowe oraz ich złącza.

11. Ludzkie systemy pojęciowe nie są monolityczne. Dopuszczają alternatywne wersje pojęć oraz perspektyw metaforycznych w wielu aspektach naszego życia. Także w matematyce: są różne koncepcje nieskończoności, różne pojęcia liczby, różne systemy logiczne, nie ma jednej tylko teorii mnogości czy tylko jednej geometrii.

12. Matematyka jest cudownym przykładem piękna, bogactwa, złożoności, różnorodności oraz ważkości ludzkich pojęć.

13. Za stworzenie matematyki odpowiedzialne są istoty ludzkie, są one też odpowiedzialne za jej rozwój.

Portret matematyki ma ludzką twarz, piszą autorzy. Można rzecz jasna twierdzić, że niektóre z wymienionych wyżej stwierdzeń to ogólniki, banały bądź metafory, a ich akceptacja nie przyczynia się do głębszego zrozumienia czym właściwie jest matematyka i skąd się wzięła. Jak odpowiadać na takie pytania? Autorzy widzą takie podstawy matematyki następująco (Lakoff, Núñez 2000: 376): 
If there are "foundations" for mathematics, they are conceptual foundations - mind-based foundations. They would consist of a thorough mathematical idea analysis that worked out in detail the conceptual structure of each mathematical domain, showing how those concepts are ultimately grounded in bodily experience and just what the network of ideas across mathematical disciplines looks like.

This would be a major intellectual undertaking. We consider this book an early step in that direction.

\section{Komentarze krytyczne}

Kto mógłby kompetentnie ocenić na ile powyżej przedstawiona wizja matematyki jest trafna? Wskazywać można różnych kandydatów, którzy byliby upoważnieni do prób obalenia tej wizji:

1. Matematycy. Ewentualną nietrafność koncepcji autorów wykazywać mogliby matematycy podając przykłady takich pojęć matematycznych, które nie dają się otrzymać na drodze sugerowanej w omawianej książce, bądź wskazując na mechanizmy tworzenia teorii, które także umykają procesom jakiejkolwiek metaforyzacji. W tym celu trzeba zatem byłoby pochylić się nad historią matematyki w poszukiwaniu takiego studium przypadku.

2. Filozofowie. Koncepcja przedstawiona w książce niewątpliwie stoi w wyraźnej sprzeczności z Platonizmem w filozofii matematyki. Wedle zdania autorów, zwolennicy Platonizmu nie są w stanie przedstawić jakiegokolwiek naukowego uzasadnienia swoich przekonań. Ciekawe byłoby oczywiście zobaczenie, jak zwolennicy Platonizmu mogliby pokazać błędność koncepcji z omawianej książki. Formalizm w filozofii matematyki również nie przydaje matematyce ,ludzkiej twarzy”, skupia się raczej na samych wytworach pracy matematyków, a nie na mechanizmach ich twórczości. Ma także pewne trudności w objaśnianiu zmienności rozumienia pojęć matematycznych. Wreszcie, również Intuicjonizm matematyczny nie współgra z omawianą koncepcja - wszak propozycje Lakoffa i Núñeza dotyczą matematyki klasycznej. Piszącemu te słowa nie są znane prace intuicjonistów, którzy ewentualnie podejmowali próby eksplikacji genezy i funkcjonowania matematyki w terminach kognitywnych.

3. Kognitywiści. Nie jest nam także wiadomo, czy nauki kognitywne zaproponowały jakąś alternatywną wobec wyżej omawianej koncepcję genezy oraz funkcjonowania matematyki. Można także pytać, czy autorzy istotnie przestrzegają wszelkich narzucanych w naukach kognitywnych zaleceń 
oraz ograniczeń. Nie potrafimy tego rozstrzygnąć - mogliby to zrobić bądź sami kognitywiści bądź specjaliści z ogólnej metodologii nauk.

Niezależnie od tego, na ile trafne jest twierdzenie autorów o tym, że wszelkie poznanie jest poznaniem ucieleśnionym, że jego podstawą jest zatem ucieleśniony umysł (embodied mind), można zastanawiać się nad trafnością ich propozycji w tłumaczeniu genezy i mechanizmów rozwoju teorii matematycznych. Tytułem przykładu wyliczamy niżej kilka nasuwających się w związku z tym problemów.

\subsubsection{Matematyka poznana a matematyka poznawalna}

Autorzy piszą, że poznawać możemy jedynie matematykę, którą sami tworzymy. Czy płynie z tego prawomocny logicznie wniosek, że tylko taka matematyka istnieje? Nie można chyba - w całkowitej ogólności - utożsamiać pojęcia istnienia $\mathrm{z}$ pojęciem poznawalności.

Spierać się można na temat samego pojęcia poznawalności obiektów matematycznych. Gdy tworzymy zbiór potęgowy choćby najprostszego zbioru nieskończonego - zbioru wszystkich liczb naturalnych - to nie ma żadnej możliwości (w języku logiki pierwszego rzędu, w którym formułujemy teorię mnogości) - np. nazywania wszystkich elementów takiego zbioru. Jest on wszak nieprzeliczalny, a dostępne środki językowe jedynie przeliczalne. Prawie wszystkie jego elementy są niedefiniowalne w rozważanym języku. Zgadzamy się jednak na to, że mówienie o zbiorach potęgowych zbiorów nieskończonych jest sensowne.

Inny rodzajem względnej niepoznawalności obiektów matematycznych są np. funkcje, które nie są efektywnie obliczalne, dla których nie istnieje algorytm obliczania ich wartości. Tylko przeliczalnie wiele spośród wszystkich funkcji o argumentach i wartościach będących liczbami naturalnymi to funkcje rekurencyjne. Potrafimy konstruować funkcje, które nie są rekurencyjne (na mocy stosownych twierdzeń teorii rekursji), potrafimy nawet sensownie mówić o różnych stopniach nieobliczalności, nie zmienia to jednak faktu, że istnieja funkcje, które w pewnym sensie są nam (efektywnie) niedostępne poznawczo.

$\mathrm{Z}$ drugiej strony, jeśli tezę autorów o ucieleśnionym charakterze matematyki brać bardzo dosłownie, to np. logiki infinitarne, czyli takie, w których dopuszcza się nieskończone alternatywy i koniunkcje lub reguły wnioskowania o nieskończonej liczbie przesłanek (jak np. $\omega$-reguła) w żadnej mierze nie mogłyby reprezentować jakichkolwiek naszych inferencji, skoro jesteśmy tworami jedynie skończonymi: w rzeczywistych wnioskowaniach nie moglibyśmy ani użyć nieskończonej koniunkcji, ani skorzystać z infinitarnej reguły wnioskowania. Potrafimy jednak sensownie o takich systemach logicznych mówić, badamy ich własności, itd. 
Powyższe argumenty można nazwać całkiem naiwnymi. Istotnie, jeśli dobrze rozumiemy propozycje autorów, to chodzi im raczej o inny rodzaj niepoznawalności. Wykluczają oni istnienie Matematyki Transcendentalnej, niedostępnej poznaniu przez ucieleśniony umysł i również nie tworzonej przez taki umysł. Nie chcielibyśmy być aż tak radykalni, jak autorzy. Pozwólmy sobie mianowicie na żywienie przekonania, że:

1. Być może, istnieje transcendentalna matematyka.

2. Jej istnienie jest całkowicie obojętne $\mathrm{z}$ punktu widzenia matematyki uprawianej przez ludzi.

Przekonanie to oddziela, jak sądzimy, praktykę badawczą matematyki (tej ludzkiej) od życzeniowych poglądów na temat matematyki (zarówno tej ludzkiej, jak i tej - być może istniejącej - transcendentalnej). Jest wyrazem agnostycyzmu matematycznego, chciałoby się może rzec.

\subsubsection{Przeliczalne i nieprzeliczalne}

Czy BMI, podstawowa intuicja nieskończoności w ujęciu autorów jest w stanie należycie zdać sprawę z tego, jak rozumiemy (czy choćby próbujemy zrozumieć) moce nieprzeliczalne? Powyżej wspomnieliśmy o niedefiniowalności elementów zbiorów nieprzeliczalnych. Zastanówmy się jeszcze przez chwilę nad intuicjami wiązanymi z pozaskończonymi skalami liczb: porządkowych oraz kardynalnych.

Zarówno liczby porządkowe, jak też liczby kardynalne to dobrze określone obiekty matematyczne:

1. Zbiór $\alpha$ nazywamy liczba porzqdkowq, jeśli jest on przechodni (czyli $\bigcup \alpha \subseteq$ $\alpha$ ) oraz liniowo uporządkowany przez relację $\in$.

2. Liczbę porządkową $\alpha$ nazywamy liczba kardynalna, gdy nie jest ona równoliczna z żadną liczbą porządkową $\beta$ taką, że $\beta \in \alpha$.

Wyposażeni w takie (bądź równoważne) definicje, powinniśmy dobrze rozumieć oba te pojęcia. Bezpiecznie możemy uważać, że dobrze rozumiemy zarówno wszystkie skończone liczby porządkowe, jak i najmniejszą nieskończoną liczbę porządkową $\omega$. W myśl propozycji autorów, gwarantuje nam to BMI, podstawowa metafora nieskończoności. Dalej, dostępne rozumieniu powinny też być te wszystkie liczby porządkowe, które tworzymy wyłącznie z liczb skończonych oraz z $\omega$, poprzez stosowanie operacji arytmetycznych, zdefiniowanych dla tych liczb porządkowych. To daje nam wszystkie liczby porządkowe aż do $\varepsilon_{0}$, czyli kresu górnego ciągu liczb $0,1, \omega, \omega^{\omega}, \omega^{\omega}, \ldots$ A co dalej? Czy BMI w wersji podanej przez 
autorów upoważnia nas do stwierdzenia, że - jakoś intuicyjnie, bazując na BMI potrafimy ogarnąć rozumieniem także np. nieprzeliczalne liczby porządkowe? Jak wiadomo, każda liczba porządkowa mniejsza od $\varepsilon_{0}$ daje się przedstawić w postaci normalnej Cantora, która jest łatwo uchwytna intuicyjnie.

W ogólności, należy odróżniać zdefiniowanie jakiegoś obiektu matematycznego od możliwości jego opisania (w ustalonym systemie znakowym). W przypadku liczb porządkowych rozważa się różne systemy notacji, które pozwalają niektóre z nich właśnie opisać. Dla przykładu, wszystkie rekurencyjne liczby porządkowe są liczbami przeliczalnymi mniejszymi od $\omega_{1}^{C K}$, która jest jedynie liczbą przeliczalną. Powyżej tej liczby możemy jedynie definiować większe liczby porządkowe, ale nie możemy ich - w żaden efektywny sposób - opisywać. Nie miejsce tutaj na omawianie różnych systemów notacji dla liczb porządkowych. Chcieliśmy jedynie zwrócić uwagę na ową istotną różnicę między definiowaniem a opisywaniem obiektów matematycznych. Jeśli propozycje autorów dotyczą metaforycznego ujmowania definiowania obiektów matematycznych, to trzeba zdawać sobie sprawę, że takie metafory mogą mieć w ogólności charakter niepredykatywny.

\subsubsection{Zdania nierozstrzygalne a praktyka matematyczna}

Autorzy piszą wyraźnie, że współczesna matematyka nie jest monolitem, w tym sensie, że rozważa się różne teorie dotyczące jej podstawowych pojęć: różne teorie mnogości, różne geometrie, różne systemy logiczne. Przy ich jawnym sprzeciwie wobec Platonizmu jest to dość oczywiste, bo przecież zadaniem takiej matematyki nie jest opisywanie jakiejś jednej, istniejącej niezależnie od badających, struktury Platońskich bytów matematycznych. Matematyka jest swobodną twórczością, posiadającą co prawda pewne ograniczenia, jak choćby wymóg niesprzeczności. Na to Lakoff i Núñez powinni przystać, jak sądzimy. Matematyka jest także twórczością przekornq, na co dowodów dostarcza jej historia, np.:

1. Algebra. Wiadomo z historii algebry, że np. liczby ujemne oraz urojone przyjmowane były z wielkimi początkowo oporami - dość długo trwało, zanim uznane one zostały za byty matematyczne prawomocnie istniejące. Do tego uznania przyczyniły się w pierwszym względzie chyba ustalenia, że liczby całkowite oraz liczby zespolone tworzą dobrze zachowujace sie struktury - w pierwszym przypadku pierścień, w drugim ciało, w dzisiejszej terminologii. W oswajaniu ich widzimy jednak również pewien odcień przekory właśnie - dopuśćmy istnienie nowych bytów matematycznych, choć konserwatywna wspólnota matematyków dotąd się przed nimi wzbraniała. 
2. Geometria. Stworzenie geometrii nieeuklidesowych wymagało zaiste wielkiego aktu przekory. Z jednej strony, skoro wysiłki zmierzające do udowodnienia aksjomatu o równoległych nie przynosiły efektu, to niejako naturalne było przypuszczenie, że aksjomatu tego nie da się właśnie wyprowadzić z pozostałych. Ale samo rozważenie (jednej z dwóch wersji) jego zaprzeczenia było przekorne, przy powszechnym przecież ówcześnie przekonaniu, iż geometria ma prawdziwie opisywać rzeczywistość fizyczną.

3. Teoria mnogości. Jedna z metod tworzenia nowych zbiorów nieskończonych jest - wedle Andrzeja Mostowskiego - następująca. Przypuśćmy, że konstruując zbiory za pomocą operacji opisanych w aksjomatach teorii mnogości, które przyjęliśmy dotychczas, napotykamy stale na zbiory o pewnej własności $P$. Jeśli nie ma oczywistych powodów, które skłaniałyby nas do przyjęcia twierdzenia, że każdy zbiór ma własność $P$, to przyjmujemy nowy aksjomat, stwierdzający, że istnieją zbiory właśnie nie posiadające własności $P$. W ten sposób otrzymujemy np. liczby mierzalne.

Jest warte zastanowienia, jak sądzimy, czy podane propozycje autorów tworzenia wszelkich pojęć matematycznych na drodze metaforycznej obejmują takie przekorne sytuacje.

Istnienie zdań nierozstrzygalnych w takich podstawowych teoriach matematycznych jak arytmetyka oraz teoria mnogości jest swoistym wyzwaniem dla intuicji matematycznych (dotyczących nie tylko liczb i zbiorów, ale także zbudowanych z nich struktur). W przypadku arytmetyki nie możemy dokonać arbitralnego rozstrzygnięcia, polegającego na dodaniu zdania nierozstrzygalnego jako nowego aksjomatu (w przypadku, gdy wiemy, które ze zdań nierozstrzygalnych $\alpha$ bądź $\neg \alpha$ jest prawdziwe $\mathrm{w}$ modelu standardowym arytmetyki), ponieważ arytmetyka jest istotnie nierozstrzygalna - żadne jej rekurencyjne rozszerzenie nie jest rozstrzygalne. Wynik ten przenosi się na teorię mnogości, gdyż arytmetykę możemy w teorii mnogości interpretować.

Zwróćmy uwagę na empiryczny fakt: nikt raczej nie kwapi się do uznania hipotezy kontinuum lub uogólnionej hipotezy kontinuum (albo, alternatywnie ich zaprzeczeń) za ewentualny dodatkowy aksjomat teorii mnogości. Rozważane we współczesnej teorii mnogości aksjomaty istnienia bardzo dużych liczb kardynalnych nie przesądzają niczego o hipotezie kontinuum. Początkowo były one traktowane jako całkowicie nieuzasadnione, obecnie niektóre $\mathrm{z}$ nich (jak choćby postulat istnienia liczb kardynalnych mocno nieosiaggalnych) są już traktowane jako „oswojone” - są wykorzystywane w dowodach wielu twierdzeń, uznaje się, że podają jakieś naturalne rozumienie hierarchii kumulatywnej zbiorów, itd. Wykazano również ich związek z „siłą niesprzeczności” (consistency strength) teorii. Jednak ewentualne decyzje co do uznania lub odrzucenia hipotezy kontinuum muszą jeśli będą - być podjęte na innej drodze. 
Zdania nierozstrzygalne wykryte zostały stosunkowo niedawno. Być może, dopiero dziesiątki (setki?) lat praktyki matematycznej przesądzą coś na temat akceptacji niektórych z nich, bądź nakażą rozwijanie odnośnych teorii w takich kierunkach, że problem tej akceptacji zniknie.

\subsubsection{Kilka przykładów topologicznych}

Jeśli nawet zgodzić się, że topologia ogólna bierze swoje początki z uogólnień związanych bezpośrednio ze znanymi dotąd strukturami - geometrią oraz badaniem zbiorów liczb rzeczywistych - to zauważyć trzeba, że jej rozwój dość szybko dostarczył przykładów konstrukcji istotnie odbiegających od wszelakiego doświadczenia potocznego. Rozważmy kilka ad hoc wybranych przykładów:

1. Sfera rogata Alexandera. Jest to powierzchnia homeomorficzna ze sferą $S^{2}$. Dzieli całą przestrzeń trójwymiarową na dwa obszary, przy czym obszar wewnątrz sfery rogatej jest homeomorficzny z wnętrzem zwykłej sfery, ale obszar na zewnątrz sfery rogatej nie jest homeomorficzny z obszarem na zewnątrz zwykłej sfery. Tak więc, twierdzenie Jordana o krzywej zamkniętej na płaszczyźnie nie uogólnia się do trzech wymiarów.

2. Jeziora Wada, krzywa Knastera, itp. Zgodnie ze wspomnianym wyżej twierdzeniem Jordana, każda krzywa zamknięta na płaszczyźnie rozcina tę płaszczyznę na dwa obszary i jest ograniczeniem każdego z nich. Istnieją jednak krzywe na płaszczyźnie, które są wspólnymi ograniczeniami trzech obszarów (a nawet dowolnej skończonej liczby obszarów). Konstruuje się różnorakie kontinua (np. kontinua dziedzicznie nierozkładalne), których własności daleko odbiegają od wymienionych wyżej (prototypowych wedle Pierponta) własności ,grzecznych” krzywych.

3. Przenicowanie sfery $S^{2}$ w przestrzeni $\mathbb{R}^{3}$. Wynik ten, uzyskany w 1958 roku przez Stephena Smale'a, głosi, że sferę $S^{2}$ można w $\mathbb{R}^{3}$,,wywrócić na drugą stronę", czyli przekształcić tak, iż jej strona wewnętrzna stanie się zewnętrzną, a przy tym nie powstaną w trakcie tego nicowania żadne nieregularności, choć wystąpi samoprzenikanie się powierzchni tak odwracanej sfery. Technicznie rzecz ujmując, wynik ten polega na wykazaniu homotopijnej równoważności dwóch zanurzeń sfery $S^{2} \mathrm{w} \mathbb{R}^{3}$. Jest to wynik wysoce niezgodny z intuicjami potocznymi, choć możliwe są nawet jego ,wizualizacje", w postaci modelu fizycznego. Dodajmy, że okręgu $S^{1}$ nie można przenicować w przestrzeni $\mathbb{R}^{2}$.

4. Sfery egzotyczne. Przez sfere egzotycznq rozumiemy w geometrii różniczkowej rozmaitość różniczkowalną, która jest homeomorficzna ze „zwykłą” 
sferą $\mathrm{w}$ przestrzeni euklidesowej $n$-wymiarowej, lecz nie jest z nią dyfeomorficzna. Pierwszy przykład takiej sfery (siedmiowymiarowej) podał John Milnor w latach pięćdziesiątych XX wieku. Nie wiadomo obecnie (2011), czy istnieją egzotyczne sfery czterowymiarowe.

5. Egzotyczna $\mathbb{R}^{4}$. Przez egzotyczna $\mathbb{R}^{4}$ rozumiemy rozmaitość różniczkowalną, która jest homeomorficzna z przestrzenią euklidesową $\mathbb{R}^{4}$, lecz nie jest z nią dyfeomorficzna. Istnieje kontinuum niedyfeomorficznych struktur różniczkowych na $\mathbb{R}^{4}$. Wymiar 4 jest tu wyróżniony: dla żadnej $n \neq 4$ nie istnieją struktury egzotyczne na $\mathbb{R}^{n}$.

Jarosław Hašek pisał: Bardzo trudno jest opisywać nieistniejace zwierzeta, ale jeszcze trudniej jest je pokazywać. W każdym zaawansowanym dziale matematyki spotykamy obiekty oddalone bardzo daleko od potocznych intuicji dnia codziennego. Prawdziwe o nich stwierdzenia również nie przekładają się bezpośrednio na prawdy zdroworozsądkowe, którymi moglibyśmy dzielić się z bliźnimi w kolejce do dentysty, bez narażenia się na podejrzenie o nienormalność, czasem wyzwiska, a w najgorszym przypadku nawet dotkliwe pobicie. Fakty te nie przesądzają, rzecz jasna, że propozycje autorów rozumienia wszelkich pojęć matematycznych jako spiętrzonych hierarchii metafor są nietrafne. Należy jedynie jasno sobie uświadomić, że ta hierarchia musiałaby być wielce skomplikowana.

Skoro jesteśmy przy przykładach topologicznych, to może warto jeszcze wspomnieć choćby o wysiłkach topologów zmierzających do trafnego, przydatnego w całej ogólności pojęcia wymiaru przestrzeni topologicznej. Trzy dobrze opracowane pojęcia wymiaru (mały i duży wymiar indukcyjny oraz wymiar pokryciowy) pokrywają się ze sobą w przypadku ośrodkowych przestrzeni metrycznych, natomiast rozchodzą się w szerszych klasach przestrzeni. Czy sensowne jest zatem pytanie, które z tych pojęć jest trafne? „Rekonstrukcja metaforyczna”, w stylu proponowanym przez autorów, powinna jakoś odzwierciedlać te problemy związane z poszukiwaniem definicji pojęcia wymiaru w topologii.

\subsubsection{Zmienność intuicji matematycznych}

Intuicje matematyczne - w odróżnieniu od intuicji związanych z doświadczeniem potocznym - są dynamiczne, przynajmniej w odniesieniu do zawodowych matematyków. Zmienność tych intuicji powodowana jest różnymi czynnikami. Wykrycie antynomii w proponowanej teorii matematycznej zmusza do jej usunięcia, przez zmianę przyjmowanych założeń, a zatem przez zmianę rozumienia pewnych pojęć rozważanej teorii. Sytuacje takie zdarzały się wielokrotnie w dziejach matematyki. Również rozpoznanie jakiegoś wyniku jako paradoksalnego może jeżeli paradoks dotkliwie nam doskwiera, o ile burzy jakieś fundamentalne dotychczasowe intuicje - doprowadzić do rozwijania teorii w takim kierunku, aby 
owo napięcie poznawcze eliminować. Może też zdarzyć się tak, że paradoks - rozumiany jako zderzenie wyniku matematycznego z intuicją potocznq-pozostaje: jest wtedy oznaką tego, że intuicja matematyczna różni się w danej sprawie od intuicji potocznych. Taka sytuacja nie dziwi w matematyce, bo przecież dlaczego $n p$. intuicja potoczna miałaby ingerować w rozumienie np. konstrukcji wykorzystujących bardzo duże liczby kardynalne albo zbiory niemierzalne. Najbardziej interesujące - dla samych matematyków - są chyba te przypadki, gdy mamy do czynienia ze zderzeniem różnych intuicji matematycznych. Dla przykładu:

1. Aksjomat wyboru oraz aksjomat determinacji są wzajem sprzeczne, aczkolwiek za każdym z nich kryją się jakieś - uważane za całkiem rozsądne intuicje matematyczne. Oczywiście, ich rola w teorii mnogości jest różna: aksjomat wyboru dotyczy dowolnych zbiorów, aksjomat determinacji tylko podzbiorów przestrzeni Baire'a.

2. Aksjomat konstruowalności Gödla jest sprzeczny z aksjomatem istnienia liczb mierzalnych. Przy założeniu aksjomatu konstruowalności zbiór potęgowy każdego zbioru składa się jedynie z jego podzbiorów definiowalnych. $\mathrm{Z}$ kolei istnienie liczb mierzalnych pociagga za sobą istnienie miary, która ma atrakcyjne - w pewnym sensie - własności.

3. Skończone matryce logiczne wydają się tworami, które powinny być opisywane w jakiś regularny sposób. Istnieją jednak takie matryce skończone, które nie są skończenie aksjomatyzowalne - por. (Pałasińska 1994), (Wojtylak 1979).

4. Ciagi von Misesa (ciągi nieskończenie dystrybutywne, których dowolny podciąg też jest nieskończenie dystrybutywny) wydają się być dobrymi kandydatami na matematyczne reprezentacje ciągów catkowicie losowych. Kłopot w tym, że ciągi von Misesa nie istnieja - zob. np. (Davis, Hersh 1994: 147-149).

5. Aksjomatyczne ujęcie pojęcia spełniania (tzw. klasy spełniania) zawiera klasyczne ujęcie tego pojęcia, podane przez Alfreda Tarskiego, jako przypadek szczególny. W ogólności, klasy spełniania dalekie są od jednoznacznej charakterystyki pojęcia spełniania, a ponadto wykazują inne jeszcze patologie - np. każą czasem uznawać za fałszywą nieskończoną alternatywę zdań prawdziwych - zob. np. (Murawski 1995).

To tylko kilka ad hoc dobranych przykładów. Sądzimy, że problem zmienności intuicji matematycznych stanowi interesujące wyzwanie dla koncepcji proponowanej przez autorów. Cóż w szczególności miałoby znaczyć, że jedne metafory wypierane są przez inne w rozwoju matematyki? 
Koncepcja Lakoffa i Núñez stara się - w pewnym zakresie - uwzględnić ową dynamikę zmian rozumienia niektórych pojęć matematycznych: widać to np. w tych fragmentach ich książki, w których opisują oni program dyskretyzacji matematyki. Można wskazać liczne dalsze przykłady zmian rozumienia pojęć matematycznych. Zmiany te mogą być powodowane, jak już wyżej wspomnieliśmy koniecznościq - np. koniecznością usunięcia antynomii. Dla przykładu, intuicyjne przekonanie, że każda własność wyznacza zbiór prowadzi do sprzeczności: nie istnieje wszak zbiór wszystkich zbiorów, zbiór wszystkich liczb porządkowych, czy wreszcie zbiór tych wszystkich zbiorów, które nie są własnymi elementami. Te antynomie udaje się wyeliminować stosownie formułując aksjomaty teorii mnogości, a w szczególności aksjomat wyróżniania. Intuicje mogą ulegać zmianom na skutek przyjęcia jakiegoś programu w danej dyscyplinie matematycznej. To właśnie miało miejsce w przypadku programu arytmetyzacji analizy: geometryczne oraz kinematyczne intuicje zostały zastąpione konstrukcjami czysto arytmetycznymi. O takich programowych zmianach możemy też mówić w przypadku teorii mnogości, przy czym na zmiany te wpływ miało wiele czynników, m.in.:

1. Porzucenie przekonania, że uniwersum teorii mnogości miałoby być charakteryzowane przez jakiś ekstremalny aksjomat minimalności - np. aksjomat ograniczenia Fraenkla, mówiący - w uproszczeniu - że istnieją tylko te zbiory, których istnienie daje się udowodnić z aksjomatów.

2. Porzucenie przekonania (z naiwnej teorii mnogości), że mówimy wyłącznie o jednym uniwersum ,prawdziwych” zbiorów. Próbowano co prawda podawać warunki, przy których otrzymujemy kategoryczność stosownego systemu mnogości - np. w (Zermelo 1930), lecz później wysiłki badaczy skierowane były raczej na studia nad różnymi modelami teorii mnogości.

3. Wykrycie całej plejady zdań niezależnych od aksjomatów teorii mnogości Zermela-Fraenkla. Pokazało to, jak słabo aksjomaty owe charakteryzują pojęcie zbioru i relację należenia. Niektóre z tych zdań niezależnych związane są z własnościami jednej z najbardziej podstawowych struktur matematycznych - zbioru liczb rzeczywistych (oraz rodziny jego podzbiorów).

4. Poszukiwanie nowych aksjomatów, które moglibyśmy ewentualnie dodawać do aksjomatyki Zermela-Fraenkla. Argumenty za ich akceptacją mogą przywoływać np. wielość i wagę otrzymywanych z nich konsekwencji, bądź - jakoś rozumiana - ich naturalność.

Oto co pisze np. Joan Bagaria na temat programu Gödla (Bagaria 2005: 4748, thumaczenie: JP): 
Wedle Gödla jest pięć takich zasad: Intuicyjny zasięg, Zasada Domkniecia, Zasada Odbicia, Ekstensjonalizacja oraz Jednostajność.

Pierwsza zasada, Intuicyjnego zasiegu to zasada intuicyjnego tworzenia zbiorów, która wcielona jest w aksjomaty ZFC. Zasada Domknięcia może zostać podłączona pod Zasade Odbicia, którą można podsumować następująco: uniwersum $V$ wszystkich zbiorów nie może zostać jednoznacznie scharakteryzowane, tj. odróżnione od wszystkich swoich odcinków początkowych przez jakąkolwiek własność wyrażalną w dowolnej rozsądnej logice wykorzystującej relację należenia. Słabą formą tej zasady jest dowodliwe w ZFC twierdzenie o odbiciu, autorstwa Montague i Levy'ego - zob. (Kanamori 1994):

Dowolne zdanie jezzyka teorii mnogości pierwszego rzedu, które zachodzi $w V$, zachodzi również w pewnym $V_{\alpha}$.

Zasada Odbicia Gödla jest dokładnie rozszerzeniem tego twierdzenia na logiki wyższych rzędów, logiki infinitarne, itd.

Zasada Ekstensjonalizacji stwierdza, że $V$ spełnia ekstensjonalną postać Aksjomatu Zastępowania i jest wprowadzona dla uzasadnienia istnienia liczb kardynalnych nieosiagalnych. [...]

Zasada Jednostajności stwierdza, że uniwersum $V$ jest jednostajne, w tym sensie, że jego struktura jest wszędzie podobna. W sformułowaniu Gödla (Wang 1996: 8.7.5): Te same lub podobne stany rzeczy pojawiajq się stale na nowo (być może $w$ bardziej skomplikowanych wersjach). Mówi on też, że zasada ta mogłaby zostać nazwana zasadq proporcjonalności uniwersum, zgodnie z którą analogony własności małych liczb kardynalnych prowadzą do dużych liczb kardynalnych. Gödel twierdzi, że ta zasada umożliwia wprowadzenie liczb kardynalnych mierzalnych lub silnie zwartych, jako iż te pojęcia dotyczące dużych liczb kardynalnych otrzymywane są przez uogólnienie pewnych własności $\omega$ na liczby kardynalne nieprzeliczalne.

O podobnych programach możemy też mówić w innych działach matematyki - za przykład niech służy chociażby topologia algebraiczna, w której badanie własności topologicznych czyni się łatwiejszym poprzez przejście do stosownych charakterystyk algebraicznych przestrzeni topologicznych.

$$
* * *
$$

Teoria metafor poznawczych dobrze się sprawdziła w lingwistyce. Czy równie dobrze sprawdza się w odniesieniu do matematyki? Piszący te słowa jest w tej sprawie sceptykiem - niektóre powody tego sceptycyzmu podano wyżej. 


\section{Rozumienie wzoru Eulera $e^{i \pi}+1=0$}

Ten rozdział to - rozłożona na części - analiza przypadku. Autorzy starają się pokazać, jak zastosować ich ujęcie - tworzenie pojęć matematycznych na drodze budowy metafor - w objaśnieniu znaczenia wybranego twierdzenia matematycznego, a mianowicie słynnego wzoru Eulera (w którym występuje pięć ważnych stałych matematycznych i obecne są dodawanie, mnożenie i potęgowanie i który to wzór bywa czasem nazywany najpiękniejszym wzorem matematyki):

$$
e^{i \pi}+1=0
$$

Nie omawiamy w szczegółach tego rozdziału w niniejszej notatce - dość może powiedzieć, że autorzy objaśniają czytelnikowi, czym są liczby $e$ oraz $\pi$, jak rozumieć potęgowanie o wykładniku rzeczywistym i zespolonym, czym jest postać trygonometryczna liczby zespolonej, itd. Oczywiście wykorzystują przy tym stosowne metafory. W efekcie czytelnik ma uzyskać to, co zdaniem autorów najważniejsze: rozumienie (w tym przypadku, rozumienie wzoru Eulera, rozumienie dlaczego jest on prawdziwy). W przekonaniu autorów owo rozumienie to coś więcej niż przyswojenie sobie definicji oraz prześledzenie dowodu. Aby uzyskać rzeczywiste rozumienie w matematyce trzeba, zdaniem autorów, odwoływać się zawsze do metaforycznej natury pojęć matematycznych.

Autor uprzejmie dziękuje wszystkim, którzy zechcieli przekazać mu swoje uwagi krytyczne na temat tego tekstu, a w szczególności Panom Profesorom: Piotrowi Błaszczykowi, Andrzejowi Grzegorczykowi, Andrzejowi Wiśniewskiemu oraz Pawłowi Zeidlerowi. Za wszelkie ewentualne lapsusy w powyższych elukubracjach odpowiedzialność ponosi wyłącznie autor.

\section{Bibliografia}

Bagaria, J. 2005. Natural Axioms of Set Theory and the Continuum Problem. W: P. Hájek, L.V. Villanueva, D. Westerståhl (red.) Proceedings of the 12th International Congress of Logic, Methodology and Philosophy of Science. London: Kings College Publications.

Batóg, T. 2000. Dwa paradygmaty matematyki. Poznań: Wydawnictwo Naukowe UAM. 
Jerzy Pogonowski: Geneza matematyki wedle kognitywistów

Błaszczyk, P. 2007. Analiza filozoficzna rozprawy Richarda Dedekinda "Stetigkeit und irrationale Zahlen”. Kraków: Wydawnictwo Naukowe Akademii Pedagogicznej.

Bukovský, L. 1979. Štruktúra reálnej osi. Bratislava: VEDA, Vydavatel'stvo Slovenskej Akadémie Vied.

Dedekind, R. 1872. Stetigkeit und Irrationale Zahlen. Braunschweig: Friedrich Vieweg \& Sohn. Wydanie 10.

Gelbaum, B.R., Olmsted, J.M.H. 1990. Theorems and Counterexamples in Mathematics. New York: Springer-Verlag.

Gelbaum, B.R., Olmsted, J.M.H. 2003. Counterexamples in Analysis. Mineola, New York: Dover Publications, Inc.

Kanamori, A. 1994. The Higher Infinite. Large Cardinals in Set Theory from Their Beginnings. Berlin: Springer-Verlag.

Lakoff, G., Johnson, M. 1980. Metaphors we live by. Chicago: University of Chicago Press.

Lakoff, G., Núñez, R.E. 2000. Where Mathematics Comes From. How the Embodied Mind Brings Mathematics into Being. New York: Basic Books.

Mioduszewski, J. 1996. Ciagłość. Szkice z historii matematyki. Warszawa: Wydawnictwa Szkolne i Pedagogiczne.

Murawski 1995. Kłopoty z prawdą, czyli o niejednoznaczności i patologiach klas spełniania. W: Pogonowski, J. (red.) 1995. Eufonia i Logos. Ksiega pamiatkowa ofiarowana Professor Marii Steffen-Batogowej oraz Tadeuszowi Batogowi. Poznań: Wydawnictwo Naukowe UAM, 467-481.

Pałasińska, K. 1994. Three-element nonfinitely axiomatizable lattices. Studia Logica 53, 361-372.

Steen, L.A., Seebach, J.A., Jr. 1995. Counterexamples in Topology. New York: Dover Publications, Inc.

Wang, H. 1996. A logical journey: From Gödel to Philosophy. Cambridge, Mass.: MIT Press.

Wise, G.L., Hall, E.B. 1993. Counterexamples in Probability and Real Analysis. New York: Oxford University Press. 
Wojtylak, P. 1979. An example of a finite though finitely non-axiomatizable matrix. Reports on Mathematical Logic 17, 39-46.

Zermelo, E. 1930. Über Grenzzahlen und Mengenbereiche: Neue Untersuchungen über die Grundlagen der Mengenlehre. Fundamenta Mathematicae 16, $29-47$. 